\title{
Rival Worlds and the place of the Corporation in International Law
}

\author{
Sundhya Pahuja ${ }^{1}$ and Anna Saunders ${ }^{2}$
}

\begin{abstract}
Struggles 'over' international law in the period between 1955 and 1974 should be understood not as a battle to control a pre-existing international law in an extant world, but instead as marking a series of encounters between rival practices of world making, each of which travelled with rival accounts of international law. The question of the corporation, how it should be conceptualized, and its proper relation to law and state, was a key element of those rival stories. In this paper, we will deploy a novel methodological orientation toward an 'historically inflected jurisprudence', to the (successful) effort to establish the UN Commission on Transnational Corporations, and the (unsuccessful) attempt to draft a binding convention on Trans National Corporations. This telling institutional moment reveals that the struggle over the proper understanding of the relationship between international law, the state, and corporation-which-travels was a struggle between rival practices of authorization, invoking both the authorship of worlds, as well as the authority to govern them. Paying attention to such practices shows us that the battle lines were drawn in ways which upset the comfortable rehearsal of a North-South divide. Anti-colonial struggles, the incipient 'Cold War', the invention of Development, and the implementation of a (Marshall) Plan to (re)construct Europe, all played into the generation of rival imaginaries and competing anxieties, producing unexpected commonalities include coalitions across North and South, and instructive alliances of interest between 'public' and 'private' actors. Slowing down our study of this moment reveals that much of what was a stake then remains so today, and that other worlds are still possible.
\end{abstract}

\section{Introduction}

Struggles in the arena of international law and institutions in the years between 1955 and 1974, should be understood not so much as a battle to control a pre-existing international law in an already-constituted world, but instead as marking a series of encounters between rival practices of world-making, ${ }^{3}$ which travelled with rival accounts of international law. The question of the corporation $^{4}$ - how it should be understood, its relationship to both law and the state, and how it travels - was a key element of those rival worlds.

In this chapter, we sketch the lineaments of that encounter through an account of the (successful) effort to establish the UN Commission on Transnational Corporations, and the (unsuccessful)

\footnotetext{
${ }^{1}$ Professor of Law, Melbourne Law School, Director, Institute for International Law and the Humanities, University of Melbourne, Visiting Professor, Birkbeck, University of London, Fulbright Senior Scholar (2016) Harvard Law School, Institute for Global Law and Policy.

2 JD Student, Melbourne Law School and former Editor, Melbourne Journal of International Law.

${ }^{3}$ N. Goodman, Ways of Worldmaking (1978).

${ }^{4}$ We are using the terms 'company' and 'corporation' interchangeably in this chapter, but there is a story to be written about the different traditions of thought to which they each belong, and the implications of their respective usages.
} 
attempt to draft a binding treaty. In our critical redescription of this telling institutional moment, we pay particular attention to how legal forms emerge and are stabilised as authoritative, and to what might be at stake in that stabilisation. ${ }^{5}$ In historically inflecting the legal and institutional story in this way, we discover that the struggle over the proper understanding of the relationship between international law, the state, and the 'multinational' corporation had two distinct layers, one which operated within what has retrospectively become the usual frame of reference, and another more radical layer which contested the frame itself.

Looking back from today, we tend to see only the more familiar level of the contest which centres on the question of whether or not the presence of foreign corporations, and foreign investment more generally, were 'good for development'. This battle appears as a set of pre-constituted actors (companies, developed states, developing states and international institutions) disagreeing about the nature and effect of the interactions between them. But if we slow down our reading and take a different imaginative vantage point than the 'now', the struggle over the corporation reveals itself to engage two a priori issues, both questions of authority and of form. The first was whether a company should be understood as a 'private', or 'political', entity. ${ }^{6}$ The second was whether a corporation could 'travel', or maintain its legal personality across jurisdictional lines, and if so, under what conditions. ${ }^{7}$ Together these questions of form were expressed as the problem of how to control the negative social, economic and distributive effects generated by highly mobile and economically powerful corporations.

\footnotetext{
${ }^{5}$ Our methodological orientation is engaged rather than explained in this short chapter. The idiom in which we are writing may be described as a novel methodological orientation toward an 'historically inflected jurisprudence'. For previous engagements with this, see S. Pahuja, 'Letters from Bandung: Encounters with Another Inter-National Law' in L. Eslava, M. Fakhri and V. Nesiah (eds), Bandung, Global History and International Law: Critical Pasts and Pending Futures (forthcoming, 2017); S. Pahuja and C. Storr, 'Rethinking Iran and International Law: The Anglo-Iranian Oil Company Case Revisited' in J. Crawford et al (eds), The International Legal order: Current Needs and Possible Responses: Essays in Honour of Djamchid Momtaz (2017) 53; S. Pahuja, 'Public Debt, the Peace of Utrecht and the Rivalry between Company and State' in A. Soons (ed.), The 1713 Peace of Utrecht and Its Enduring Effects (forthcoming, 2017). For a forthcoming engagement which includes an exposition of the method, see Pahuja's inaugural annual lecture for the Leiden Journal of International Law. Given on 26 October 2016 as 'The Changing Place of the Corporation in International Law', it will be published in the LJIL. On 'critical redescription', see Sundhya Pahuja, 'Laws of Encounter: A Jurisdictional Account of International Law', 1 London Review of International Law (2013) 63.

${ }^{6}$ On this question, see D. Ciepley, 'Beyond Public and Private: Toward a Political Theory of the Corporation' 107 American Political Science Review (2013) 139. See also M. Horwitz, 'History of the Public/Private Distinction', 130 University of Pennsylvania Law Review (1982) 1423. See also S. Dorsett and S. McVeigh, 'Jurisprudences of Jurisdiction: Matters of Public Authority' 23 Griffith Law Review (2014) 569.

${ }^{7}$ Horwitz discusses the seminal cases exploring this question across state lines within the United States, Western Union Telegraph Co v Kansas, 216 US 1 (1910); Pullman Co v Kansas, 216 US 56 (1910); Ludwig v Western Union Telegraph Co, 216 US 146 (1910); Southern Railway Co v Greene, 216 US 400 (1910). Horwitz, 'History', supra note 6.
} 
In contrast to these a priori questions of enframing, the redescribed question as to whether or not the presence of foreign corporations was 'good for development' was empirically unresolvable at any level of generality - the devil was always in the detail. ${ }^{8}$ And slowing down our reading of the period also shows us that the battle lines around even what we take to be that more familiar question were more complex than they now appear. Those lines were drawn in ways which upset a comfortable rehearsal of a North-South divide. ${ }^{9}$ The incipient 'Cold War', Sino-Soviet Rivalry, ${ }^{10}$ the invention of 'Development', and the implementation of a (Marshall) Plan to (re)construct Europe all played into the generation of rival imaginaries and competing anxieties, producing both unexpected commonalities across what was to become a North-South 'divide', and instructive alliances of interest between what we now think of as 'public' and 'private' actors.

And yet precisely because of its political valencies and empirical irresolvability, the 'mere' redescription of the issue through a developmentalist lens was key to the stabilisation of the juridical outcomes sought by the United States and its friends. These were 'formal' outcomes in the strictest sense of the word. Specifically, in the framing of the disagreements as political questions over whether the 'protection' of foreign property belonged in the domestic or international sphere, and over whether the regulation of corporate conduct should be internationalised or left to the domestic sphere, an implicit resolution was effected of crucial questions of legal form.

Thus in the 'success' of establishing the UNCTC as a forum for dispute over the relationship between companies and states, what was stabilised was an enframing of that dispute which carried with it an account of private property as a universal institution, and the corporation as both 'private', and as able to travel freely with its personality intact. And so, what was experienced as a (minor) victory is perhaps better understood in the genre of tragedy. ${ }^{11}$ For that juridical (or more properly 'jurisdictional' $)^{12}$ defeat paved the way not only for political defeat in the failure of the attempt to craft a treaty which addressed the conduct of multinational corporations directly, but also in the decades-later efflorescence of investor-state arbitration, which together produced a series of outcomes precisely opposite to those sought by the Third World and its friends.

\section{Instituting the Battle Lines}

\footnotetext{
${ }^{8}$ D. K. Fieldhouse, The West and the Third World: Trade, Colonialism, Dependence, and Development (1999).

${ }^{9}$ N. Miskovic, H. Fischer-Tiné and N. Boskovska (eds), The Non-Aligned Movement and the Cold War (2014).

${ }^{10}$ J. Friedman, Shadow Cold War: The Sino-Soviet Competition for the Third World (2015).

${ }^{11}$ See D. Scott, Conscripts of Modernity: The Tragedy of Colonial Enlightenment (2004). For an account of the 'narrative arc of tragedy' see S Critchley, 'Tragedy's Philosophy and Philosophy's Tragedy' (Humanities Center Annual Lecture, Brigham Young University, 2014). See also A. Khan, 'Inheriting a Tragic Ethos: Learning from Radhabinod Pal', AJIL Unbound (2 August 2016).

${ }^{12}$ See generally S. Dorsett and S. Mcveigh, Jurisdiction (2012); Pahuja, 'Laws of Encounter', supra note 5.
} 
The multinational companies are the 'chartered companies' of modern times.

Mohammed Bedjaoui, $1979^{13}$

The long backstory to the question of the multinational corporation is colonialism. The jurisdictional and historical story of companies in that context is too complex for our purposes here, but two elements bear mention. The first is that regardless of how they are theorised, the chartered or 'colonial' companies had been experienced in much of the world not simply as agents of empire, but as themselves imperial masters. ${ }^{14}$ This mastery was not effected simply through the exercise of 'private' power, but of political, or public authority. ${ }^{15}$ As Bedjaoui was later to put it, the chartered companies enjoyed 'the right to recruit armed forces, levy taxes and make regulations' ${ }^{16}$ They also made laws, adjudicated disputes and administered territory. ${ }^{17}$ The second element is that by the middle of the nineteenth century, and after several crucial shifts in the quality of the ongoing encounters between the European and non-European worlds ${ }^{18}$ the idea of private property, and its ownership by foreigners, was being protected outside Europe through multiple modalities of violence. Colonialism, economic coercion and force or its threat in the form of 'gunboat diplomacy'19 ${ }^{19}$ were all elements of that protection. As the twentieth century dawned and the legitimacy of protecting foreign property ownership through force was questioned, both the US and European states tried to assert a legal basis for the protection of private property, including that being claimed by foreign corporations. But this 'legal' basis remained both putative and contested, ${ }^{20}$ and as decolonisation proceeded, the foreign ownership of property - particularly by transnational corporations - became a key site of struggle. ${ }^{21}$

\footnotetext{
${ }^{13}$ Towards a New International Economic Order (1979), 36-37.

${ }^{14}$ See for example, Ngũgĩ wa Thiong'o ‘Resisting Metaphysical Empire: Language as War Zone' (John La Rose Memorial Lecture, 2013). See also P. Stern, The Company State: Corporate Sovereignty and the Early Modern Foundations of the British Empire in India (2011).

${ }^{15}$ This is mostly theorised as delegated sovereignty, however Sundhya Pahuja's current research relates to a different theorisation of this authority - one which is beyond the scope of this article. On the question of the exercise of public authority, see also Dorsett and Mcveigh, 'Jurisprudences of Jurisdiction', supra note 6; See also, J. McLean, Searching for the State in British Legal Thought: Competing Conceptions of the Public Sphere (2012); P. Mahoney, 'Contract or Concession? An Essay on the History of Corporate Law', 34 Georgia Law Review (2000) 874.

${ }^{16}$ Bedjaoui, supra note 13.

${ }^{17}$ Stern, supra note 14.

${ }^{18}$ Two tipping points but with complex implications around this time were the 'Opium Wars' between Britain and China (1839-1842), and later, Britain and France and China (1856-1860), and the acquisition of ruling powers over India in August 1858 (after the 1857 Rebellion) by the Government of India Act 1858 - pursuant to which the East India Company was formally dissolved and its ruling powers over India were transferred to the British Crown.

${ }^{19}$ A. Vagts, Defense and Diplomacy: The Soldier and the Conduct of Foreign Relations (1958); C. Lipson, Standing Guard: Protecting Foreign Capital in the Nineteenth and Twentieth Centuries (1985).

${ }^{20}$ Borchard, for instance, in 1915, writes in relation to the question of legal personality, that 'there is more uncertainty as to the extent of the obligation to recognize the legal capacity of foreign corporations': E. M. Borchard, The Diplomatic Protection of Citizens Abroad, or, the Law of International Claims (1915) 41. The Drago (debt) and Calvo (investor-state disputes) doctrines were both opposed to the idea that a right of
} 
The new post-war institutions quickly became a site of that struggle. In the context of the success of the anticolonial struggles, both those institutions and the fact of institutionalisation itself seemed to hold out the glimmer of a promise of an international society organised around nationstates rather than empires, and in which the fragile principle of formal sovereign equality held at least some meaning. That meaning centred on staving off the 'neocolonial' international order which threatened to replicate the political economy of empire in the guise of universal legality. ${ }^{22}$ And despite its fragility, such a society seemed to offer the chance to assert a form of legal authority over companies long seen as illegitimate and exploitative. ${ }^{23}$

And so by the time of the Bandung conference of 1955, the non-European World was using international fora to denounce imperial systems of labour, production, agriculture, extraction, and finance in both the formal colonies and in the wider 'spheres of influence', as having been geared toward the satisfaction of the needs of the 'Metropole', and the immiseration of the rightful inhabitants of the colonies. ${ }^{24}$ The experience of the Latin American states, nominally independent since the nineteenth century, ${ }^{25}$ also provided evidence for many that the colonial mode of 'integrating' places and people into a 'world economy', as well as developing an 'international division of labour', ${ }^{26}$ created enduring economic structures, and patterns of integration, which would continue the impoverishment of the Third World into the future and deepen international inequalities. ${ }^{27}$ The 'multinational corporation' as it came to be known after about $1960,{ }^{28}$ was widely

diplomatic protection inhered in states with respect to the treatment of foreign property. See M. Sornarajah, The Pursuit of Nationalized Property (1986) 11. Contrast this to some extent with the argument made in Lipson, supra note 20.

${ }^{21}$ Indeed, the NIEO was eventually to address this problem head on. See for example, A.Anghie, 'Legal Aspects of the New International Economic Order', Humanity (March 2015).

${ }^{22}$ On neo-colonialism, see for example, F. Fanon, 'First Truths on the Colonial Problem' in Toward the African Revolution (Trans. F. Maspero, 1967, first published 1964).

${ }^{23}$ A good example of this is the Anglo-Persian oil company in Iran: see Pahuja and Storr, supra note 5.

${ }^{24}$ If not well before. See L. Eslava, M. Fakhri and V. Nesiah (eds), Bandung, Global History and International Law: Critical Pasts and Pending Futures (forthcoming, 2017).

${ }^{25}$ For example, Ecuador, 1810; Venezuela, 1810; Paraguay, 1811; Argentina, 1816; Chile, 1818; Colombia, 1819; Mexico, 1821; Peru, 1821; Guatemala, 1821; Nicaragua, 1821; Costa Rica, 1821; Panama, 1821; Brazil, 1822; Bolivia, 1825; Uruguay, 1825. But Cuba and the Dominican Republic did not gain independence from the United States until 1902 and 1924 respectively, while Puerto Rico remains a territory.

${ }^{26}$ Fieldhouse, supra note 8 . See generally chapter 6 , 'The Concept of a Colonial Economy' which contains a magisterial survey of much of the literature.

${ }^{27}$ See, in general, the 'dependency theorists', who argued that that the way poor states are integrated into the 'world system' creates a resource flow from a 'periphery' of poor and underdeveloped states to a 'core' of wealthy states, further enriching the latter at the expense of the former: H. Singer, 'The Distribution of Gains between Investing and Borrowing Countries' 40 American Economic Review (1950) 479; R. Prebisch, The Economic Development of Latin America and Its Principal Problems (1950); A. Gunder Frank, The Development of Underdevelopment (1966); C. Furtado, Economic Development of Latin America: Historical Background and Contemporary Problems (1976); P. Baran, The Political Economy of Growth (1957). See also W. Rodney, How 
understood, from the perspective of both the 'Second' and Third Worlds, to be a key moving part in this structural account of the 'world economy,' potentially continuing the role of the chartered companies.

But by the very early 1960's, despite the invention of an international rubric addressed to the question of material need, ${ }^{29}$ and a decade inaugurated by international institutions in its name, ${ }^{30}$ it had become clear that countries in the Third World were not benefitting from these institutional efforts. Indeed, for many, their economic position relative to the First World was declining. ${ }^{31}$ At the international institutional level, Latin American economists led the drive to change the perceived structural features of the 'world economy' which were seen to induce the dependency of the 'periphery'. ${ }^{32}$ They did this through a range of measures, starting with a series of resolutions in the UN General Assembly asserting the right to nationalise land and resources as part of the doctrine of 'Permanent Sovereignty over Natural Resources,',33 and later through the initiation of an intergovernmental forum at the United Nations on trade and development as a way of tackling the unfavourable terms of trade. ${ }^{34}$ The realisation that the position of the Third World was not likely to improve under current rules encouraged those in the South increasingly to assert a radical account of the emergent concept of development, understood in terms of political-economy rather than through the technical lens (favoured by the First World) of 'development economics'. ${ }^{35}$ It also

Europe Underdeveloped Africa (1972) (on Africa); S. Amin, 'L'afrique de l'ouest bloquée: l'économie politique de la colonisation, 1880-1970 (1970) (on West Africa); T. Raychaudhuri, 'Conclusion: Empire in Retrospect' in P.J. Marshall, The Cambridge Illustrated History of the British Empire (1996).

${ }^{28}$ Fieldhouse, supra note 8 at 260. Fieldhouse (following Mira Wilkins) attributes the neologism to David Lilienthal, one-time head of the Tennesee Valley Authority, who it seems probably coined the term between 1958 and 1960.

${ }^{29}$ This was of course 'development'. S. Pahuja, Decolonising International Law: Development, Economic Growth and the Politics of Universality (2011). On the continuity between development, the civilising mission, and before that, Christian tropes of salvation, see J.L. Beard, The Political Economy of Desire: International Law, Development and the Nation State (2007).

${ }^{30}$ United Nations Department of Economic and Social Affairs, The United Nations Development Decade: Proposals for Action (1962).

${ }^{31}$ See K. Sauvant, 'From Economic to Socio-Cultural Emancipation: The Historical Context of the new International Economic Order and the New International Socio-Cultural Order' 3 Third World Quarterly (1981) 48, 50 .

32 Examples include the establishment of the UN Economic Commission for Latin America and the Carribean (ECLA or CEPAL in Spanish). Argentine economist Raúl Prebisch was a key figure in this kind of structuralist economic thought. Prebisch was appointed as the inaugural Secretary-General of UNCTAD: D. Cordovez, 'The Making of UNCTAD: Institutional Background and Legislative History' 1 Journal of World Trade Law (1967) 243, 272.

${ }^{33}$ Pahuja, Decolonising International Law, supra note 29. See also GA Res. 1803 (XVII), 14 December 1962.

${ }^{34}$ This started life as an ad hoc conference but became a permanent institution in 1964: GA Res. 1995 (XIX), 30 December 1964. See also Cordovez, supra note 32.

${ }^{35}$ Sauvant writes that, prior to the 1970s, economic development had largely been approached as a technical, rather than a political, matter: K. Sauvant, The Group of 77: Evolution, Structure Organization (1981) 4. See also Sauvant, From Economic to Socio-Cultural Emancipation', supra note 31, 55; GA Res. 3202 (S-VI), 1 May 1974. For a brief account of the emergence of the discipline of development economics, see S.N. Engel, 
prompted a push for the establishment and strengthening of institutional arenas in which new policies for 'international development' could be formulated.

The establishment of the United Nations Conference on Trade and Development (UNCTAD) was one expression of that push. At a meeting in Cairo in 1962, 'thirty-six nations representing the three major regions of the Global South' called for the creation of a forum at which to discuss 'all vital questions relating to international trade, primary commodity trade, [and] economic relations between developing and developed countries'. ${ }^{36}$ Despite opposition from almost all nations of the European Economic Community, many of whom feared such a conference would threaten the prevailing legal-economic order underpinned by the (European) Common Market and the GATT, ${ }^{37}$ 'UNCTAD' was eventually convened, inaugurated as a conference rather than the permanent institution it was later to become. ${ }^{38}$

At the conclusion of the first conference, in June of 1964, a group of seventy-five countries issued a joint declaration on a new agenda for trade and development. ${ }^{39}$ Along with the promotion of that agenda, in which UNCTAD I was positioned as a 'significant step towards creating a new and just world economic order ${ }^{40}$, the declaration was a forging-place of the Group of 77 , or ' $\mathrm{G} 77$ '. ${ }^{41}$ In order to achieve the desired transformation, the Group stressed the importance of establishing 'international machinery in the field of trade and development' which was democratically run and which provided equal representation to all states. ${ }^{42}$ At the next meeting of the Group, in Algiers in 1967, the Group resolved to hold a Ministerial Meeting prior to each session of UNCTAD 'in order to harmonize the positions of developing countries and to formulate joint programmes of action in all matters related to trade and development ${ }^{\prime}{ }^{43}$

'Development economics: from classical to critical analysis', in R. A. Denemark (Eds.), The International Studies Encyclopedia Volume II (2010) 874-892.

${ }^{36}$ G. Garavini, After Empires: European Integration, Decolonization, and the Challenge from the Global South (2012) 35. See also Cairo Declaration of Developing Countries (18 July 1962).

${ }^{37}$ With the exception of the Netherlands: Garavini, supra note 36, 35.

${ }^{38}$ ECOSOC Res 917 (XXXIV), 3 August 1962; GA Res 1785 (XVII), 8 December 1962

39 Joint Declaration of the Seventy-Seven Developing Countries Made at the Conclusion of the United Nations Conference on Trade and Development, 15 June 1964.

40 Ibid.

${ }^{41}$ Sauvant, 'From Economic to Socio-Cultural Emancipation', supra note 31, 50. The two subsequent recruits to the Group were the Republic of Korea and the Republic of Viet Nam: Sauvant, The Group of 77, supra note 35, 18-19. The name persisted despite the membership numbering, by 1980, 122 countries: at 3.

42 Joint Declaration.

${ }^{43}$ Charter of Algiers, 25 October 1967. The second such meeting was held in Lima in 1971, producing the Declaration and Principles of the Action Programme of Lima. See Declaration and Principles of the Action Programme of Lima, 7 November 1971.. For a discussion of the Algiers ministerial conference and the opening statement made by Algerian president Hourari Boumedienne, see Garavini, supra note 36, 75-6. 
Levels of co-operation of this kind were internationally unprecedented, and although the political orientations of this large group of countries were inevitably disparate, ${ }^{44}$ a sense of solidarity operated as a counterweight to the effect of political diversity. This sense arose from the shared burden of history, the experience of the 'racialism' of Europe and the United States, ${ }^{45}$ the legacies of empire, the either-or choices being produced by the 'Cold War' between the Soviet Union and the United States, and to a different extent, China, ${ }^{46}$ and the explicit attempts to take control of the new international fora by Europe and the United States. And so political solidarity sought its expression in a new institutional as well as legal framework - with the first seen from the outset as being critical to the second. This drove several initiatives, including the agenda of what was to be a fateful third conference from the perspective of the company question. ${ }^{47}$

\section{UNCTAD III - Decolonising political economic imaginaries?}

The third session of UNCTAD was held in Santiago de Chile, between 13 April and 21 May 1972. As president of the country hosting the event, Salvador Allende gave the opening speech. ${ }^{48}$ Allende's speech must have been electrifying. ${ }^{49}$ In a clarion call to action, Allende outlined the mission of the third session as continuing the work of replacing the 'outdated and essentially unjust economic and trade order'. ${ }^{50}$ Colonialism could not be forgotten while it cast long shadows over both national and international political-economies. Even after their formal decolonization, many countries 'exist[ed] under unbearable conditions...their economy [still] dominated by foreign powers; outsiders hold[ing]

\footnotetext{
${ }^{44}$ Ranging from more pragmatic (Asia and Africa) to radically progressive (Latin America): Garavini, supra note 36, 38, 134.

${ }^{45}$ S.Pahuja, 'Letters from Bandung', supra note 5.

${ }^{46}$ See for example, N. Miškovic, H. Fischer-Tiné \& N. Boškovska, The Non-Aligned Movement and the Cold War: Delhi, Bandung, Belgrade (2014) and J. Friedman, Shadow Cold War: The Sino-Soviet Competition for the Third World (2015).

${ }^{47}$ Sauvant, The Group of 77, supra note 35, 2-3, 9-10.

${ }^{48}$ Allende was a democratically elected socialist and accordingly, a troubling figure for the United States, which had expended much effort in trying to prevent his election and topple him when we was elected, finally engineering the infamous coup of General Augusto Pinochet. On the investigations by the US Senate of such covert activities, see Hearings Before the Select Committee to Study Governmental Operations with Respect to Intelligence Activities of the United States Senate, Ninety Fourth Congress, First Session, Volume 7: Covert Action (1975). Available at https://www.intelligence.senate.gov/resources/intelligence-related-commissions [website last visited 10 June 2017].

${ }^{49}$ The journalist for the Observer wrote that 'Western delegates, expecting a platitudinous inauguration, writhed in their seats as the Chilean leader, conscious that he was speaking for virtually the whole of the Third World, tore into the trade and aid practices of rich countries. [...] Few orators could successfully have followed that speech [...] As Allende left the rostrum ...covered symbolically in Chile's main export, copper, the atmosphere was electric. One Western European Cabinet Minister looked almost apoplectic. A Scandinavian delegate chuckled quietly that one could have expected nothing less from a country which was being squeezed in a vice by the US'. H. O'Shaughnessy, 'Poor Nations Warn: Give Us a Better Deal or Else', , The Observer, 16 April 1972.

${ }^{50}$ Proceedings of the United Nations Conference on Trade and Development: Third Session, 1973, vol 1, UN Doc TD/80, Annex VIII, 'Address Delivered by Mr Salvador Allende Gossens, President of Chile at the Inaugural Ceremony on 13 April 1972, [9] ('Allende's UNCTAD III Address').
} 
all or part of their territory; they still endure[d] the yoke of colonialism...deep social disparities oppress[ed] the masses and benefit[ted] only the privileged few'.$^{51}$

And yet despite these tentacular legacies of empire, Allende was hopeful. World developments since the last session of the Conference had created a moment in which transformative change was possible. ${ }^{52}$ 'The financial conceptions of the post-war period are tottering,' he said, and the 'new or strengthened centres of political and economic power [would generate] striking changes of front among the industrialized countries,.$^{53}$ Having already seen the beginnings of a new era of 'coexistence and dialogue' between capitalist and socialist countries, Allende speculated that the same might be possible for the colonial powers and formerly colonised 'dependent peoples'. ${ }^{54}$ Growing instances of successful resistance, and imperial defeats, as well as the energising political solidarity between the peoples of the global South, led him to be certain that they would reject an international order which perpetuated 'their backward state'. Instead, 'they will seek and they will obtain their economic independence and will conquer underdevelopment ${ }^{25}$

But if his rhetoric was impassioned, Allende's analysis offered no illusions. ${ }^{56}$ Chile was under immense pressure from multinational corporations resistant to its plans to nationalise key sections of the Chilean economy, and they were openly interfering in Chilean sovereignty. ${ }^{57}$ The concert between the American Central Intelligence Agency and those same corporations to destabilise Allende, as they had others before him, was already notorious. For Allende, not only was a more just Chile under threat, but the unchecked power and further expansion of multinational corporations would be fatal to the new worlds being made through Third World solidarity, and would scuttle the possibility of cooperation between the developed and the developing world. The question of the large multinational corporation was thus thrust onto the stage of international institutionalism, and the agenda for the rest of the conference was set.

\footnotetext{
51 Ibid [12].

52 Ibid [49], [96]. He referred here to both China's recent entry into the 'international community', and the 'invincible heroism' of Viet Nam, where communism, as an alternative model of socio-economic ordering, had risen despite resistance from both former imperial powers and local elites.

${ }^{53}$ Ibid [50]. He also attributed the potential for change to 'a tide of new technical and scientific discoveries': at [54].

${ }^{54}$ Ibid [97].

${ }^{55}$ Whether peacefully, through 'cooperation, based on solidarity, justice and respect for human rights' or alternatively being forced to take the path of 'conflict, violence and suffering': Ibid [108]-[109].

${ }^{56}$ One could also read his hope as threatening from the perspective of those with vested interests in the maintenance of the system he was attacking. As much is plain from the CIA-backed coup d'etat led by Augusto Pinochet which, on 11 September 1973, deposed Allende and led to his death. See for example, W. Blum, Killing Hope: US Military and C.I.A Interventions since World War II (2004, first published 1995).

${ }^{57}$ A. Sampson, The Sovereign State of ITT (1973).
} 
Allende's critique of the corporation operated at the radical - or 'root' - level alluded to above, engaging a priori questions of how the company should be understood, and how the company-state relation should be enframed. Although Allende deployed the term 'development ${ }^{58}$ as a rhetorical proxy for the question of material well-being, ${ }^{59}$ he related it neither to an internationalised promise, nor to an instrumentalised programme. Instead, he reminded the assembled conference of the imperial origins of foreign investment, which although 'often presented as an instrument for progress, has almost always proved negative in its effects, ${ }^{60}$ and made it clear that it was through its recent conceptual connection to 'development' that 'self-interest and altruism' seemed suddenly to be compatible.

He understood that the rhetorical merger between self-interest and altruism - a 'dual mandate' for the present $d a y^{61}$ - had long been deployed by foreign corporations who represented their actions as being in the interests of those whose resources they exploited, but even more crucially, that this story provided authority for their actions. ${ }^{62}$ Multinational corporations 'which arrogate to themselves the role of agents promoting the progress of the poorer countries [...] have become a supranational force that is threatening to get completely out of control' ${ }^{63}$ Acting with authority in his account, rather than simply exercising power, Allende suggested that corporations should be understood as political, rather than private entities, who threatened to compete with states on the international stage. These companies would not act in conformity with agreements amongst states, he warned, but would instead adhere to their own interests and policies:

[t]hey have their objectives, their own policies with regard to trade, shipping, international affairs and economic integration, their own view of things, their own activity, their own world. We spend our time at international meetings discussing the visible features of the third world's structure of dependence, while its underlying determinants slip by us unseen, like the submerged three quarters of an iceberg. ${ }^{64}$

\footnotetext{
${ }^{58}$ On the institutionalisation of development, see Pahuja, Decolonising International Law, supra note 29.

${ }^{59}$ By now the terms was thoroughly institutionalised as a proxy for this conversation. See generally, G. Rist, The History of Development: From Western Origins to Global Faith (2014, Trans. P. Camiller.)

${ }^{60}$ Allende's UNCTAD III Address, supra note 50, [16].

${ }^{61}$ F. Lugard, The Dual Mandate in British Tropical Africa (1922).

${ }^{62}$ One could also say that it provided 'legitimacy'. However in this piece, we place emphasis on the question of authority and practices of authorisation rather than legitimacy and legitimisation.

${ }^{63}$ Allende's UNCTAD III Address [18], [58].

${ }^{64} \mathrm{Ibid}$ [59]-[61]. Another story to be told is the way in which the secrecy shrouding the commercial world, or the world of the corporation, becomes or remains unquestionable - the Chilean example being an exception to this general rule.
} 
As Allende repeatedly pointed out, this was not an historically new phenomenon. Through the control of key industries such as telecommunications and mining, multinational corporations threatened to capture the current moment of change and to repeat the experience of the Industrial Revolution, which had represented 'a mere transition from colonial to neo-colonial status' ${ }^{65}$ And, by subtle yet pervasive methods of intervention, he warned, they would eventually undermine the norm of non-intervention that was the foundation of the international legal order. ${ }^{66}$

Allende offered the Chilean experience as instructive, both in respect of corporate interventions in the south, as well as with respect to the claims of the First World, that multinationals brought beneficial flows of foreign direct investment. ${ }^{67}$ In order to counter the influence of multinationals, and to capitalise on the possibilities offered by the Conference, continued cooperation and unity among the countries of the developing world was essential. ${ }^{68}$ The delegates would need both to 'face the world as it is, defending [themselves] against illusions and mystifications', but also to 'throw[] wide the gates of imagination' to create a replacement for the post-colonial order. ${ }^{69}$ Otherwise, in Allende's words, the 'new hopes that promise liberation may lead only to new forms of colonialism'. ${ }^{70}$

For Allende, a key element of the power of the transnational corporation lay in both its mobility visà-vis the state, and detachment from the nation in both effective and affective terms. His speech to the General Assembly on 4 December 1972 puts the point succinctly;

\begin{abstract}
'We are witnessing a pitched battle between the great transnational corporations and sovereign states, for the latter's fundamental political, economic and military decisions are being interfered with by worldwide organisations which are not dependent on any single State, and which, [...] activities, are not accountable to or regulated by any parliament or institution representing the collective interest. In a word, the entire political structure of the world is being undermined. "Merchants have no country of their own. Wherever they
\end{abstract}

\footnotetext{
65 Ibid [55].

66 Ibid [62].

${ }^{67}$ See Fieldhouse, supra note 8 . Allende had begun the process of nationalising the copper and minerals industries after his election, but much harm to the Chilean economy had already been done. According to the financial records of the copper companies, the original investment they had made in Chile was $\$ 30$ million, but they had since extracted over $\$ 4,000$ million from Chile - almost equalling the Chilean debt - without any further investment: ibid [40].

${ }^{68}$ Allende's UNCTAD III Address, [27]-[28].

69 Ibid [11].

${ }^{70}$ Ibid [53].
} 
may be they have no ties with the soil. All they are interested in is the source of their profits." Those are not my own words; they were spoken by Jefferson. ${ }^{71}$

The mobility of the large corporations, and the corresponding challenge that posed for the existing political order prompted the delegates at UNCTAD III to argue for new, internationalised forms of regulation. As the Chilean representative stated, it was 'no longer possible to ignore the serious gap in the system of international institutions, namely, the lack of any arrangements for the supervision and regulation of the activities of multinational corporations' ${ }^{72}$ De Seynes, then Under-Secretary General for Economic and Social Affairs, emphasised that in the absence of such regulation 'it would be increasingly difficult to rely, for a development policy, on the combined advantages of financial resources, technology, managerial capacity and world-wide distribution networks that international corporations could offer'. ${ }^{73}$ Instead, as Argentinian economist Raul Prebisch stated, what was needed was for the developed world to abandon its 'geocentric approach' and to take seriously the interests and concerns of the developing countries, acknowledging them as different from its own. ${ }^{74}$

Ultimately, Allende's critique, and the shared concerns of many of the delegates, would be taken up at the Conference in two forms. The first was through conceptualising the problem of corporate behaviour through the lens of 'restrictive business practices'. ${ }^{75}$ The second was to respond to the mounting evidence that foreign private investment had a detrimental impact on the economies of the countries which received such investment, through asking how such impact might be remediated and minimised through law - whether domestic or international. Although still much broader than the turn to business and human rights that was to come some thirty years later, what was already being lost in this enframing were the more radical questions about the benefits of private foreign investment per se, as well as an attention to the continuities between older forms of corporate activity and the current international order.

\section{Second Committee - Restrictive Business Practices}

\footnotetext{
71 'Address by Mr Salvador Allende, President of the Republic of Chile', Summary Records of the $2096^{\text {th }}$ meeting of the UN General Assembly, 4 December 1972, UN Doc. A/PV.2096, [59] ('Allende's UNGA Address'). The original quote is from The Writings of Thomas Jefferson (1861) 334.

72 United Nations Conference on Trade and Development, Third Session, Vol 1a, Part Two: Summary Records of Plenary Meetings, $93^{\text {rd }} \mathrm{mtg}, 57$ (Chile).at.

${ }^{73} \mathrm{lbid}, 89^{\text {th }}$ plen mtg, 372 (De Seynes, Under-Secretary-General for Economic and Social Affairs).

${ }^{74}$ Then Under-Secretary General and Director of the Latin American Institute for Economic and Social Planning, as well as former Secretary-General of UNCTAD: Ibid, $103^{\text {rd }}$ plen $\mathrm{mtg}, 383$.

${ }^{75}$ On the future of the code on restrictive business practices, see J. Davidow, 'The UNCTAD Restrictive Business Practices Code' 13 International Lawyer (1979) 587; D. Oesterle, 'United Nations Conference on Restrictive Business Practices' 14 Cornell International Law Journal (1981) 1.
} 
The Second Committee of the 1972 conference ${ }^{76}$ took up the question of the effect of 'restrictive business practices on developing countries, and the possibility of their regulation. ${ }^{77}$ From the outset, however, the definition of restrictive business practices' was contested. Most could agree that cartel practices to exclude imports or restrict exports should be included, but based on their experience, many from the South would also include contractual practices inhibiting integration with the local economy, intellectual property used to inhibit the promised benefits of technology transfer, ${ }^{78}$ and 'the activities of multinational corporations and [...] their contribution to the export efforts of developing countries'. ${ }^{79}$ As the Director of Manufactures, Krishnamurti, pointed out, '[i]n some cases, the restrictions were not explicit in contractual arrangements but implicit in the nature of control exercised by a foreign enterprise over a firm in a developing country'. ${ }^{80}$

The language of restrictive business practices had its origins at least as far back as the Havana Charter of $1948 .^{81}$ However, participants at the 1972 Conference agreed that although the Havana Charter could usefully be examined as part of the work of the proposed expert group, the chapter on restrictive business practices ${ }^{82}$ would need to be revisited in light of the changed role of

\footnotetext{
${ }^{76}$ Following the pattern established by the work of the Preparatory Committee in setting up the first Conference, each Conference creates a number of sessional bodies - both numbered Committees and Working Groups - in order to facilitate the work of the Conference. The Committees are each assigned agenda items and participation in the Committees is ordinarily open to all participating States. The Conference in plenary considers and votes on resolutions either recommended or referred for further consideration by the Committees: Cordovez, supra note 32, 281. See, for examples, Proceedings of the United Nations Conference on Trade and Development, 1964, vol 1, 101-6; Proceedings of the United Nations Conference on Trade and Development: Third Session, 1973, vol 1, UN Doc TD/80, 15-17 and annexes ('UNCTAD III Proceedings'). ${ }^{77}$ UNCTAD III Proceedings, vol 1, Agenda item 14(d). Before them was a report of the UNCTAD secretariat which had been instructed to consider these practices specifically 'from the standpoint of the trade and development of developing countries': see UNCTAD Res 25(II); Second Committee, Summary Records of the Fifth Meeting, UN Doc TD/III/C.2/SR.5, 57 (Krishnamurti, Director, Manufactures Division).

${ }^{78}$ Second Committee, Summary Records of the Fifth Meeting, UN Doc TD/III/C.2/SR.5, 57 (Krishnamurti). Compare the Havana Charter, which listed 'extending the use of rights acquired under patents...to products or activities which are not within the scope of such grants' as a restrictive business practice: Havana Charter for an International Trade Organization, concluded 24 March 1948, art 46-3.

${ }^{79}$ Second Committee, Summary Records of the Fifth Meeting, UN Doc TD/III/C.2/SR.5, 57 (Krishnamurti). ${ }^{80} \mathrm{Ibid}$.

${ }^{81}$ See Havana Charter for an International Trade Organization, concluded 24 March 1948. The Havana Charter, negotiated at the beginning of the post-war era, sought to create principles for the uniform regulation of international trade, administered by an International Trade Organization: C. Wilcox, A Charter for World Trade (1949) vi-ix. See further R Toye, 'Developing Multilateralism: The Havana Charter and the Fight fot the International Trade Organization, 1947-1948' 2 International History Review (2003) 282. The Charter was concluded at the Havana conference of 1948 but never entered into force after the US withdrew its support: D.B. Furnish, 'A Transnational Approach to Restrictive Business Practices' 4 International Lawyer (1970) 317, 326.

${ }^{82}$ Chapter $V$ of that Charter contained an exhaustive list of 'restrictive business practices' that could be subject to complaint by aggrieved member states. These seem largely to have reflected concerns around corporate cartel practices, like price-fixing or exclusion from markets, which might reduce competition: Wilcox, supra note 81,110 . The Charter envisaged that the list could only be added to with a two-thirds majority support of International Trade Organization member-states: at 110.
} 
multinational corporations. ${ }^{83}$ The regime in the Havana Charter was limited in at least three ways: it contemplated only 'the publication of infringements and the pressure of public opinion' as a consequence of breaching its provisions; it relied on proof of harm as a result of any infringement rather than imposing prospective rules against particular behaviours; and enforcement of the Charter was left to individual states. ${ }^{84}$ In other words, it contained a benign image of the multinational corporation which assumed it could be subjected to low levels of control, and a view of the state as willing and able to assert this control. ${ }^{85}$

At the meeting of the Second Committee, on the other hand, representatives drew attention to the sizeable and growing power of multinational corporations as compared to most countries of the global South. Viewed through the prism of trade, for instance, de Rivero from Peru highlighted that just 300 multinational companies controlled over 40 per cent of the total volume of trade in manufactured exports from developing countries and approximately 30 per cent of international trade as a whole. ${ }^{86}$ And following Allende's evidence of corporate intervention in Chilean elections, in the view of many, this power was clearly spilling over into areas of sovereign authority. ${ }^{87}$ Against this background, the broadening of the definition was an attempt to capture the increasingly evident power relationship between company and state in political-economic context.

However, the extent to which these restrictive business practices should be understood as harmful to developing countries - and the proper role of law in dealing with such practices - was also contested. Opinions divided into three distinct groupings. In one camp, countries in which transnational corporations were operating subsidiary companies were experiencing the operations as making little, or negative contributions to the 'development project'. For their part, first world countries warned that hasty regulation would prove fatal to the ability to attract corporate activity sufficient to transform 'backward' economies. And on the part of the socialist countries (the third grouping), there was an agnosticism toward the idea of potential benefits at best, and often a wholesale rejection of the idea of foreign investment, echoing Allende's warning that such benefits would always come at the cost of independence. ${ }^{88}$

\footnotetext{
${ }^{83}$ Second Committee, Summary Records of the Seventh Meeting, UN Doc TD/III/C.2/SR.7, 83 (Israel).

${ }^{84}$ Ibid 83 (Israel).

${ }^{85}$ The story of the Havana Charter is also relevant to this story, but has been removed for reasons of space.

${ }^{86}$ Second Committee, Summary Records of the Seventh Meeting, UN Doc TD/III/C.2/SR.7, 74. See also Second Committee, Summary Records of the Sixth Meeting, UN Doc TD/III/C.2/SR.6, 65 (Bulgaria).

${ }^{87}$ Second Committee, Summary Records of the Sixth Meeting, UN Doc TD/III/C.2/SR.6, 60 (Mexico).

${ }^{88}$ Fieldhouse states there were three prevailing approaches to the economic effects of multinational corporations on the host state: a 'conventional' approach, which emphasised that at least in theory, investment benefited the host country's economy both directly and indirectly, including through wealth creation and transfer of technology; a 'radical' approach, which argues that these benefits are either
} 
Supporting the first view were the many damaging practices that had come to light through studies conducted in developing countries, and detailed in the secretariat's report. ${ }^{89} \mathrm{Mr}$ Paulos from Ethiopia, for example, pointed to the way in which multinational corporations discouraged exports from developing countries because it was against their interests to create competition between their subsidiary companies. ${ }^{90}$ The Bolivian representative, Mr Gonzalez, added that half of the parent companies were based in the United States, and around one-quarter in the United Kingdom, and that it was through these extensive subsidiary networks that multinational corporations can and did exert influence over the exports of developing countries. ${ }^{91}$ In Malaysia, for example, manufacturing companies had been unable to export their products beyond the domestic market due to restrictive clauses in their contracts with parent firms. ${ }^{92}$ The emerging international patent and trade mark system was also of particular concern as it allowed the licenser to restrict the export of goods manufactured using their intellectual property, so that 'licensers could be certain of eliminating all competition against their countries'. ${ }^{93}$

While states hosting investments tended to characterise these concerns as an unwanted corollary of corporate activity, the socialist countries saw them as intrinsic to Western European practices of investment. The size of these companies, coupled with the control exerted by their parent through the corporate structure, translated into the domination of domestic economies - and thus, for Bulgaria for instance, both posed 'an obstacle to the development of the economies of the developing countries and... [had] a nefarious impact on the exports of those countries'. ${ }^{94}$ As the report showed, even where corporations professed a desire to assist in the creation of industry in parts of Asia, Africa and Latin America, their aim in doing so was to 'consolidate the dependent status of the developing countries...to limit their industrial exports while deriving benefits from them'. ${ }^{95}$ Thus, for the socialist countries, the 'supposed advantages [of foreign investment] were more than offset by the outflow of financial resources which they generated' ${ }^{96}$

exaggerated or outweighed by the damage to local enterprise, or both; and a 'neo-conventional' approach. This third approach responded to the radicals by both accepting that the benefit for each country should be assessed on a case-by-case basis, and pointing out that, theory aside, in practice the path to development could not be walked without foreign investment: Fieldhouse, supra note 8, 267-71.

${ }^{89}$ UNCTAD III Proceedings, vol 1, Annex VI, Report of the Second Committee [182].

${ }^{90}$ Second Committee, Summary Records of the Sixth Meeting, UN Doc TD/III/C.2/SR.6, 62.

${ }^{91}$ Ibid 62-3 (Bolivia).

${ }^{92}$ Ibid 66 (C F Yee, Malaysia)

${ }_{93}^{93}$ Ibid 62 (Ethiopia);

${ }^{94}$ Ibid 65.

${ }^{95}$ Second Committee, Summary Records of the Seventh Meeting, UN Doc TD/III/C.2/SR.7, 75 (Byelorussian Soviet Socialist Republic).

${ }^{96}$ Second Committee, Summary Records of the Eighth Meeting, TD/III/C.2/SR.8, 93 (Cuba). 
In response to the evidence that transnational corporate activity was damaging the economies of host states, developed market-economy countries staked their position on the promise that such activity could make an 'overriding contribution' ${ }^{97}$ Should tighter controls be put in place around these contributions, they argued, multinational corporations would be deterred from investing and developing countries would lose the benefits of such investment. ${ }^{98}$ The 'benefits' promised were conceptually aggregated, tutelary, and amorphous. Mr Oyamada from Japan, for example, asserted that 'every country should take advantage of the merits while making the utmost efforts to eliminate the undesirable effects of [the] activities' of multinational corporations'. ${ }^{99}$ In his account, Japan itself had taken this path and was now becoming a provider, not only a recipient, of investment. ${ }^{100}$ Similarly, the United States suggested that concentrating on 'problem areas', 'entailed the risk of underestimating the major contribution which private direct investment could make to development'. France highlighted that the setting of 'too rigid standards' was likely to be a barrier to trade, even if justified on other counts. ${ }^{101}$

In direct contrast to the idea that restrictive business practices might be addressed through an international agreement of some kind, First World countries took the view that it was the responsibility of developing countries themselves to enact legislation dealing with corporate conduct. This was underpinned by the fiction of the large corporation as a 'multinational' enterprise, collaboratively conducting a business venture emanating from multiple sites, rather than a 'transnational' one, which was controlled in one place but operative in others. Ellis, from the International Chamber of Commerce, told delegates that the 'multinational enterprise' was not a single entity but a parent company with a web of subsidiaries. As such, 'each of the subsidiaries was subject to the sovereign powers of the State in whose territory it operated... [which] had the sovereign authority to enact legislation and to introduce controls to curb any harmful restrictive business practices' ${ }^{\prime 102}$ Clark of the United Kingdom stated that his government was powerless to control the terms which firms attached to the granting of licenses. These were 'a matter for the foreign country in question and the firm to settle ${ }^{103}$ In this respect, some developed countries offered their own national laws as a model for emulation. ${ }^{104}$ Australia suggested that its experience might be especially instructive, because of the relatively small size of its economy and the measures

\footnotetext{
${ }^{97}$ UNCTAD III Proceedings, vol 1, Annex VI, Report of the Second Committee, [196].

98 Ibid [196].

${ }^{99}$ Second Committee, Summary Records of the Sixth Meeting, UN Doc TD/III/C.2/SR.6, 63.

100 Ibid 63.

${ }^{101}$ Second Committee, Summary Records of the Seventh Meeting, UN Doc TD/III/C.2/SR.7, 86.

102 Ibid 79-80.

103 Ibid 70-1.

104 UNCTAD III Proceedings, vol 1, Annex VI, Report of the Second Committee [191]. See especially Second Committee, Summary Records of the Seventh Meeting, UN Doc TD/III/C.2/SR.7, 70 (UK), 84 (Denmark).
} 
it had put in place to ensure that company investment aligned with the national interest. ${ }^{105}$ Such insistence that the proper sphere of regulation was domestic, was joined by the scepticism of some toward the potential for international law to reduce these practices - Guyot, the French delegate, remarked that although treaties were 'often effective...some international confrontation and consultation procedures had never really worked' ${ }^{106}$

And yet for many, the very fact of both the obvious need for domestic legislation and its proven inadequacy in controlling the activities of multinational corporations pointed to the need for new international legal principles. As Ceylon's representative stated, 'the majority of developing countries had no means of controlling the restrictive business practices of private enterprise... The time had therefore come to study the problem and to take measures at the national and international level' ${ }^{107}$ India, despite having taken measures to align foreign investment with national priorities, found it had 'not yet been possible to control entirely the adverse effects of private foreign investments'. ${ }^{108}$ And Chile noted that while the developing countries' introduction of legislation was part of the solution - and the Andean Group's experience was instructive in this respect - neither domestic nor regional laws would be sufficient to assert control unless working in concert with international measures. ${ }^{109}$ These sentiments found echoes in those expressed by some European nations - Belgium noted that in many cases domestic legislation rendered public authorities 'powerless' to intervene in corporate activities, and new legal principles were needed to supplant it. ${ }^{110}$ In this way, delegates framed both their desire for, and ambivalence toward, a new international regime governing restrictive business practices by reference to not only economic or political, but legal (im)possibility. Ultimately, the disagreement over substance was deflected through the commissioning of an 'Ad hoc Group of Experts on Restrictive Business Practices'. ${ }^{111}$

\footnotetext{
${ }^{105}$ Second Committee, Summary Records of the Eighth Meeting, UN Doc TD/III/C.2/SR.8' 95-6 (Australia).

${ }^{106}$ Ibid 86 (France).

${ }^{107}$ Second Committee, Summary Records of the Sixth Meeting, UN Doc TD/III/C.2/SR.6, 67. See also at 62-3 (Bolivia), 65 (Bulgaria); Second Committee, Summary Records of the Seventh Meeting, UN Doc TD/III/C.2/SR.7, 69-70 (Philippines).

${ }^{108}$ Second Committee, Summary Records of the Seventh Meeting, UN Doc TD/III/C.2/SR.7, 72-3.

${ }^{109}$ Second Committee, Summary Records of the Eighth Meeting, UN Doc TD/III/C.2/SR.8, 97 (Chile). Colombia and Tunisia also called for the creation of guidelines or an international code of conduct governing the behaviour of multinationals: $6^{\text {th }}$ meeting 65 (Colombia); $7^{\text {th }}$ meeting, 89 (Tunisia). It is unclear from the debates whether these were intended to be binding or not. See further United Nations Department of Economic and Social Affairs, The Impact of Multinational Corporations on Development and on International Relations, UN Doc E/5500/Rev.1, 54-5.

${ }^{110}$ Second Committee, Summary Records of the Seventh Meeting, UN Doc TD/III/C.2/SR.7, 83.

${ }^{111}$ The temporary working group would be composed of both governmental experts in the field of international trade, as well as experts from 'competent international organizations' such as WIPO and the ICC. UNCTAD Res 73 (III). The representative from the Holy See had previously suggested that the international trade unions should be represented, but these were not specifically named in the resolution: Second
} 


\section{Debate in the Third Committee on Private Foreign Investment}

In the Third Committee, a rather more heated debate was taking place over private foreign investment and the role of multinational corporations in the world economy. ${ }^{112}$ The $\mathrm{G} 77$ had introduced a draft resolution on 'Foreign Private Investment in its Relationship to Development'. ${ }^{113}$ The resolution expressed concern about evidence of financial outflows caused by private foreign investment, its 'excessive' use of local financial resources and the disruption of competition by foreign companies operating in the markets of developing countries. ${ }^{114}$ In short, the problem was that private foreign investment was not performing what the resolution took to be its proper function, namely to 'facilitate the mobilization of internal ressources [sic], generate inflows and avoid outflows of foreign reserves, incorporate adequate technology, and enhance savings and national investment ${ }^{\prime 115}$ Instead, it was impeding rather than assisting in the project of development. The draft resolution therefore urged developed countries to 'take the necessary steps to reverse the tendency for an outflow of capital'. ${ }^{116}$

During this debate, views on whether foreign private investment was inherently beneficial or not also split between three main positions. One grouping of developing countries was hopeful that multinational corporations could contribute to development. Zaire, for instance, had taken steps to encourage and facilitate foreign private investment, including modernising national infrastructure and drafting an investment code which 'conceded a number of advantages', such as loss of tax revenue and outflows of resources. It had made these 'sacrifices...in the hope that at a second stage investment would help to raise the level of living of the population' ${ }^{117}$ Other countries shared this hope, but were more wary of making concessions. Cameroon considered that foreign private investment could further national development; but only 'so far as the government succeeded in turning it to good account...and in so far as the investors played the host country's game, so to speak ${ }^{\prime 118}$ Still others within this grouping were in the process of establishing regional schemes to regulate foreign investment, in order to capitalise on its benefits while recognising its potentially

Committee, Summary Records of the Eighth Meeting, UN Doc TD/III/C.2/SR.8, 94. The group was to report to the Committee as soon as possible.

112 UNCTAD 233.

$113 \mathrm{TD} / \mathrm{III} / \mathrm{C} .3 / \mathrm{L} / 5$.

${ }^{114}$ See, for background, the report before the Committee for consideration: Sanjay Lall, 'Balance-of-Payments Effects of Private Foreign Investment in Developing Countries: Summary of Case Studies in India, Iran, Jamaica and Kenya', UN Doc TD/134/Supp.1.

${ }^{115}$ For the text of the draft resolution, see UNCTAD III Proceedings, vol 1, Annex VI, 239, UN Doc TD/III/C.3/L/5 [2].

${ }^{116}$ Ibid [3]. This mirrors exactly the language found in the Lima Declaration: UNCTAD III Proceedings, vol 1, Annex VIII, 'The Declaration and Principles of the Action Programme of Lima' (7 November 1971) 391

${ }^{117}$ Third Committee, Summary Records of the Fourteenth Meeting, UN Doc TD/III/C.3/SR.14' 136.

${ }^{118}$ Third Committee, Summary Records of the Sixteenth Meeting, UN Doc TD/III/C.3/SR.16, 164. 
harmful aspects. The Council of the Cartagena Agreement, for example, recognised the precariousness of depending on the benevolence of investors, and had adopted a joint regime for foreign investment in $1970 .{ }^{119}$ This regime, then constituted by Bolivia, Chile, Colombia, Ecuador, and Peru, 'reserved the right to authorize foreign investment after having evaluated the conditions in which it was offered and its conformity with the development priorities of the country in which the capital was to be invested' ${ }^{120}$ Foreign purchasing of national enterprises which was considered to be of no benefit to the host country, was subject to 'special rules'. ${ }^{121}$ Likewise, re-exporting capital investment was prohibited 'except where shares were sold to national investors or where the enterprise went into liquidation'. ${ }^{122}$ Notwithstanding different approaches to corporate control, what was common was an implicit acceptance of the potentially beneficial link between foreign investment and development.

A second grouping considered that foreign private investment was critical for development and that the potential harms that worried the G77 were overstated. This view was accompanied by calls for states to further accommodate the interests of the investor. Japan, for example, called for the expansion of the role played by foreign private investment in the development process 'on conditions that took into account the requirements of both the investors and the recipient country'. ${ }^{123}$ And although the UK accepted that countries might wish to protect their legitimate interests, 'reasonable stability' in conditions within the recipient country was necessary for investment and '[s]udden and arbitrary changes in the conditions under which foreign private investors operated could only be counter-productive'. ${ }^{124}$ The US likewise asserted that private investment was critical to development and that certain actions of developing countries - such as 'expropriations in one or another form' were in danger of reducing the pool of investment available to other developing states. ${ }^{125}$ As the question of whether to invest was up to the private investor, the critical role of 'host' governments was to work out a 'mutually beneficial arrangement' which would ensure the security of that investment. ${ }^{126}$ Already, moves had been made at the institutional

\footnotetext{
${ }^{119}$ The Cartagena Agreement, signed in 1969, created the customs union (initially comprising Bolivia, Colombia, Chile, Ecuador and Peru) then known as the Andean Pact and now referred to as the Andean Community:. Agreement on Andean Subregional Integration, signed 26 May 1969, 8 ILM 190.

${ }^{120}$ Third Committee, Summary Records of the Fourteenth Meeting, UN Doc TD/III/C.3/SR.14, 140.

121 Ibid 141.

122 Ibid 141.

123 Ibid 132.

${ }^{124}$ Third Committee, Summary Records of the Sixteenth Meeting, UN Doc TD/III/C.3/SR.16, 160.

125 Ibid 157-8. The critical and expanding role of private investment in the development process, for the US, eclipsed that of the limited and finite flows of 'official development assistance'.

${ }^{126}$ Ibid 158 (United States).
} 
level to facilitate an increase in volume of foreign private investment. ${ }^{127}$ The promise of this increase came, then, with strings attached - the implicit replacement of official development assistance with foreign private investment, and the injunction to accommodate the interests of corporations as its carrier.

A third grouping resolutely opposed the idea that foreign private investment might be considered to perform the role of a catalyst for development, a role more properly performed by official development assistance. The USSR, for instance, asserted that investment 'by its very nature' was incapable of complying with the conditions outlined in the draft resolution of conforming to national priorities and stimulating capital formation. ${ }^{128}$ History had shown developing countries that in many cases investment had led to 'the complete exhaustion of their economies'. ${ }^{129}$ The direct effects of foreign private investment on the balance of payments, added Cuba, had been shown by the case studies before the committee to be overwhelmingly negative - even if the net effect was judged to be favourable. ${ }^{130}$ In addition, companies' demands for guaranteed conditions for their investment 'implied a violation of national sovereignty'. ${ }^{131}$ For this group, more research was needed on the phenomenon of capital outflows linked to foreign private investment, which led to a worsening in the monetary position of developing countries, as well as on the profits made by companies as a result of that monetary position. ${ }^{132}$ In the meantime, the USSR encouraged developing countries to take advantage of its offer of credit on terms unaccompanied by 'any political or economic tie or condition'. ${ }^{133}$

Against these divided views on how to understand the relationship between development and foreign private investment, states coalesced into two broad stances on the best way to control or otherwise regulate it. This replicated the divide which was playing out in relation to restrictive business practices in the Second Committee. One grouping - which included France, West Germany, and the United Kingdom - insisted that host states were always free to establish rules governing the conditions under which companies could invest. France declared that although it was difficult for countries to exercise 'authoritarian control' over investors, '[c]ontrol of private investment

\footnotetext{
${ }^{127}$ For example, Belgium had established a financing corporation to provide capital for investment in developing countries: Third Committee, Summary Records of the Fifteenth Meeting, UN Doc TD/III/C.3/SR.15, 152 (Belgium).

${ }^{128}$ Third Committee, Summary Records of the Fourteenth Meeting, UN Doc TD/III/C.3/SR.14, 129.

${ }^{129}$ Ibid 129.

${ }^{130} \mathrm{Ibid}$ 137. However, given the assumptions underpinning the report, Cuba also questioned the extent to which their findings were reliable. In addition, the report paid no attention to the negative impact of investment on aspects of economic life beyond the prism of balance-of-payments effects: at 138.

${ }^{131}$ Ibid 138 (Cuba).

${ }^{132}$ Ibid 129 (USSR).

${ }^{133} \mathrm{Ibid} 130$. As opposed to the terms of the capitalist countries, which 'often resembled in nature the relations that existed previously between the metropolitan countries and their colonies': at 131.
} 
nevertheless remained one of the essential attributes of the sovereignty of the host countries, which were free to fix their own rules'. ${ }^{134}$ West Germany explicitly tied the disagreement over the empirical question (was investment good for development) to the question of the appropriate regulatory jurisdiction, noting that as it was impossible to determine as a matter of principle, whether foreign investment was good or bad for development, 'each case should be separately investigated' by the host state. ${ }^{135}$ This move is illustrative of the way in which the argument about the empirical question was being reshaped toward the impossibility of international regulation. Similarly, the United Kingdom insisted that 'each investment proposal needed to be looked at on its own merits' and that where foreign investment had deleterious effects, this was generally due to the failure of the host country to properly screen the investment. ${ }^{136}$ In other words, it was for that state to make a decision about whether or not it wished to welcome the investment. Locating this decision in the host state, for this group, meant that the decision and the legal frameworks structuring it were malleable. So, France saw the Andean Pact as relatively benign, simply harmonising internal domestic arrangements. ${ }^{137}$ But the UK warned that it would be undesirable for the Andean framework to crystallise into 'rigidity' and to impede foreign private investment from being able to do its work. ${ }^{138}$ Instead, as 'it was impossible to lay down formal rules on an international basis to regulate foreign investment', the better legal vehicles according to the UK, were bilateral agreements. ${ }^{139}$

A grouping that included Algeria, Venezuela and Guyana resisted this view, each articulating in different ways a common opposition to the idea that the domestic sphere, on its own, offered a way to regulate the activities of corporations. Algeria, for instance, endorsed a unified system for the supervision and control of multinational corporations. ${ }^{140}$ For Venezuela, 'foreign private investment had been the cause of the relationships of colonialism and dependency' which were imbricated in the current international economic order. Its delegate proposed that foreign private investment should be governed in accordance with the 'principle of international social justice' geared to the

\footnotetext{
${ }^{134}$ Third Committee, Summary Records of the Fifteenth Meeting, UN Doc TD/III/C.3/SR.15, 151.

${ }^{135}$ In addition, the FRG had a policy of considering whether investment would make a contribution to the host country before providing 'investment guarantees or special credits' to the investor: Ibid 148-9.

${ }^{136}$ Third Committee, Summary Records of the Sixteenth Meeting, UN Doc TD/III/C.3/SR.16, 159-60. In other words they put forward the view, echoed by Fieldhouse, that the multinational corporation 'will only be as useful or as dangerous as the host country allows it to be': Fieldhouse, supra note 8, 285.

${ }^{137}$ Third Committee, Summary Records of the Fifteenth Meeting, UN Doc TD/III/C.3/15, 151. See also the comments of Switzerland, largely supporting the remarks made by the French representative on foreign private investment: Third Committee, Summary Records of the Sixteenth Meeting, UN Doc TD/III/C.3/SR.16, 156.

${ }^{138}$ Ibid 160 (UK)

${ }^{139}$ Ibid 160-1.

${ }^{140}$ Third Committee, Summary Records of the Fifteenth Meeting, UN Doc TD/III/C.3/15, 153.
} 
priorities needs of host countries. However, he considered that decision-making centres about those priorities should be located in the host countries themselves, pushing back against the incipient hierarchisation of authority at play in the debate. ${ }^{141}$ Guyana, on the other hand, advocated action both 'at the national level and also by pressing for a new strategy for development within the group of $77^{\prime}{ }^{142}$ Recognising that developed countries had a vested interest in existing structures of economic relations within developing countries, the solution lay in maintaining and reinforcing solidarity in the developing world itself. ${ }^{143}$ So, although a common theme was that the international was implicated in the relationship of dependency between host states and investor-corporations, no common solution or vision was articulated as a means for resolving this dilemma.

In the end, the Committee was unable to reach agreement on the draft resolution, referring it to the President of the Conference for further consideration. ${ }^{144}$ The Conference considered the draft resolution in its $118^{\text {th }}$ plenary meetings and after amendments, adopted the resolution by 73 votes to 3 , with 23 abstentions. ${ }^{145}$ The final resolution recorded the concerns of developing countries over the outflow of capital as a result of foreign investment and the failure of foreign investment to generate wealth. ${ }^{146}$ However, a number of countries emphasised their decision not to take part in the vote: the Chinese delegation noted their choice to refrain from voting, ${ }^{147}$ while the Swiss and Danish delegations considered the text was not sufficiently 'balanced'. ${ }^{148}$ The UK and the US, who voted against the resolution, considered that it did not give enough weight to the merits of private investment. ${ }^{149}$ Ultimately, the resolution affirmed only the right of developing countries to regulate foreign investment within their own legal systems, and urged developed countries to prevent the outflow of capital from the countries in which multinational corporations, through measures such as offering tax exemptions for reinvesting profits. ${ }^{150}$ It therefore did not envisage any solution which was based on international rather than domestic legal authority.

\section{A culmination of sorts? The Group of Eminent Persons' report}

\section{ECOSOC meeting 1822, 5 July 1972}

\footnotetext{
141 Ibid 157.

142 Third Committee, Summary Records of the Sixteenth Meeting, UN Doc TD/III/C.3/SR.16, 163.

143 Ibid 163.

144 UNCTAD III Proceedings, vol 1, Annex VI, 'Report of the Third Committee' [106].

${ }^{145}$ UNCTAD Res 56 (III); UNCTAD III Proceedings, vol 1, Annex II, 'Action with respect to Reports' 143.

${ }^{146}$ UNCTAD Res 56 (III), operative paragraphs 2 and 3.

147 UNCTAD III Proceedings, vol 1, Annex I, 'Observations and Reservations by Delegations on the Decisions of the Conference' 122.

${ }^{148}$ Ibid 122 (Denmark), 130 (Switzerland).

149 Ibid 132 (UK), 134 (US).

${ }^{150}$ UNCTAD Res 56 (III), operative paragraphs 1 and 4.
} 
A sense of frustration at the perceived lack of good will on the part of the First World, and the lack of progress in addressing the increasing influence of multinational corporations ${ }^{151}$ prompted the Chilean representative to the UN, Hernan Santa Cruz, to raise the issue again later that year, this time at the meeting of the Economic and Social Council ('ECOSOC'). ${ }^{152}$ For Santa Cruz, the attempts by the International Telephone and Telegraph Company (ITT) to overthrow the Chilean government laid bare the ability of large corporations to 'interfere[] in domestic affairs of countries and even in international relations'. ${ }^{153}$

Despite the agenda brought to UNCTAD III, he said, 'there ha[d] been partial, if not total, failure on many base issues.' ${ }^{154}$ In particular, the Third World had perceived a critical need to establish a comprehensive international trade organisation, recognising that 'world economic problems could not be compartmentalized' and that fragmenting deliberation on key economic issues could prejudice their interests. ${ }^{155}$ However, the G77's attempt to make UNCTAD more representative, in accordance with the principle of equitable geographical representation, and to transform it into a forum for the negotiation and adoption of multilateral trade treaties, had been stymied. ${ }^{156}$ Restating the conviction, widespread in both the Second and Third Worlds, that it was 'unwise to let those

\footnotetext{
${ }^{151}$ The general tenor of the close of proceedings at UNCTAD III was one of a commitment to continued solidarity mixed with frustration at the 'lack of goodwill' on the part of developed countries - see esp comments of Venezuela in the plenary, UNCTAD III Proceedings, vol 1a, pt 2, 'Summary Records of the Plenary Session' $334\left(119^{\text {th }}\right.$ plen $\left.\mathrm{mtg}\right)$. Chile felt that proposals to make UNCTAD a permanent institution had also been scuttled by developed states. But still, there was cause for optimism in the politics inside those states, not yet present in the official positions they took - namely movements 'within the Governments themselves and in organizations of young people, workers and even businessmen' that recognised the imperative to 'assist in the modernization of the third world': $1822^{\text {nd }}$ meeting of the Economic and Social Council, UN Doc E/SR.1822, 5 July 1972 [30] (Chile).

${ }^{152} 1822^{\text {nd }}$ meeting of the Economic and Social Council, UN Doc E/SR.1822, 5 July 1972. ECOSOC is one of the six principal organs of the UN, and one of the original institutional bodies.

${ }^{153} \mathrm{Ibid}$ [23], [34]. The story of the struggle between Chilean governments and the ITT company, which had culminated in a way in interference in the Chilean election has been told elsewhere: Sampson, supra note 57. See also P. E. Sigmund, Multinationals in Latin America: The Politics of Nationalization (1980); L. Randall, The Political Economy of Latin America in the Postwar Period (1997); E. J. Dosman, The Life and Times of Raúl Prebisch, 1901-1986 (2008)

${ }^{154} 1822^{\text {nd }}$ meeting of the Economic and Social Council, 5 July 1972, UN Doc E/SR.1822 [26]. Inflation, coupled with the increasing number of programmes funded by voluntary contributions, meant that even if industrialised countries did not succeed in their efforts to freeze the budgets of specialised agencies, UNCTAD's capacity for new initiatives was limited: at [27].

${ }^{155}$ UNCTAD III Proceedings, Annex VI, 'Report of Working Group 1' 301 (Brazil). For the opposing view, see the statement by the representative of GATT at UNCTAD III (urging the maintenance of an effective division of responsibility: at 301.

${ }^{156}$ Ibid 299 (comments by the representative of the G77). For the G77's proposed alterations to the institutional arrangements of UNCTAD, see UN Doc TD/III/WG.I/L.I/Rev.I. For the resolutions ultimately adopted, see UNCTAD Res 80(III); UNCTAD Res 81(III).
} 
new centres of economic power operate in an institutional vacuum', Santa Cruz proposed a draft resolution for a new study on multinational corporations. ${ }^{157}$

The draft resolution proposed that a group of persons 'of the highest moral and intellectual character and of international repute in their various fields' be appointed to study the problem of multinational corporations in depth. ${ }^{158}$ Unlike the UNCTAD-led expert study considering the problem of Restrictive Business Practices, ${ }^{159}$ this study would be more far-reaching, with implications for international relations as well as a range of other areas. ${ }^{160}$ As Chile proposed it, the group would be constituted by members 'from developed market-economy countries, developing countries and socialist countries, and [would] include representatives of student movements whose future was at stake'. ${ }^{161}$ An aspect of the group's task would be to remedy the gap identified by the UnderSecretary General at the Third Session of UNCTAD: the 'lack of any arrangement for the supervision and normalization of the activities of multinational corporations'. ${ }^{162}$ But like the previous deliberations in UNCTAD, the ensuing debate in the Council ${ }^{163}$ was tellingly illustrative of 'the two aspects of the problem of multinational corporations: on the one hand, "aberrations" and "distortions" ... and on the other, the undeniable role played by those corporations in...the provision of the capital needed for economic development'. ${ }^{164}$

The strongest supporters of such a study thought that companies should not remain unregulated, as a matter of international law, for activities which did not coincide with the interests of developing countries. Mexico, for instance, supported the eventual implementation of a binding code of conduct for multinational corporations on the basis that the increasingly complex structure of the world economy had given birth to multinational corporations and the only limit to their expansion was the question of profitability'. ${ }^{165}$ The representative from Peru was similarly concerned with the increasing power of multinational corporations and their potential to infringe on sovereignty. He felt that there was an 'obvious need for some measure of control over their activities or some

\footnotetext{
$1571822^{\text {nd }}$ meeting of the Economic and Social Council, UN Doc E/SR.1822, 5 July 1972, [34]-[35].

$1581831^{\text {st }}$ meeting of the Economic and Social Council, 14 July 1972, 14 July 1972, UN Doc E/SR.1831 [9].

${ }^{159}$ For the final report of this study, see Restrictive Business Practices in relation to the Trade and Development of Developing Countries: Report by the Ad Hoc Group of Experts (1974) UN Doc TD/B/C.2/119/Rev.1.

${ }^{160} 1832^{\text {nd }}$ meeting of the Economic and Social Council, 20 July 1972, UN Doc E/SR.1832 [9] (Chile). Although it would be necessary to coordinate the two.

$1611831^{\text {st }}$ meeting of the Economic and Social Council, 14 July 1972, UN Doc E/SR.1831 [9].

${ }^{162}$ See United Nations Conference on Trade and Development, Third Session, Vol 1a, Part Two: Summary Records of Plenary Meetings, $89^{\text {th }}$ plen mtg, 372 (De Seynes, Under-Secretary-General for Economic and Social Affairs).

${ }^{163} 1831^{\text {st }}-1834^{\text {th }}$ meetings of the Economic and Social Council, 14-25 July 1972, UN Doc E/SR.1831-4.

164 1832nd meeting of the Economic and Social Council, 20 July 1972, UN Doc E/SR.1832 [87] (Italy). By 'aberrations', the Italian representative referred to incidents such as the interference in the Chilean election.

$1651831^{\text {st }}$ meeting of the Economic and Social Council, 14 July 1972, UN Doc E/SR.1831, [12].
} 
international code of conduct for them' ${ }^{166}$ The USSR agreed. ${ }^{167}$ Its representative argued that recent events had demonstrated that 'that economic problems could not be considered in isolation from their political aspects,' referring particularly to the ability of large multinational companies to influence, or even alter the composition of, governments of States. ${ }^{168}$ Although the problem was an old one, he said, the difference now was that the countries being affected were 'no longer powerless to defend their interests against the multinational corporations' ${ }^{\prime}{ }^{169}$

The proposed study also found significant support among a number of Western countries (other than the United States), which had begun to witness the pernicious effects of the activities of multinational corporations on both their own economies and on their foreign relations. ${ }^{170}$ As such, they were eager to have the study assess 'the impact of multinational corporations' activities on both developed and developing countries'. ${ }^{171}$ Even the UK, which had opposed the resolution on foreign investment put forward at UNCTAD III, felt the study would be useful for this reason. ${ }^{172}$ However, these states wanted the study to 'be of a technical character and...not go into the political implications of the issue ${ }^{\prime 173}$ lest it meant 'foregoing the concentration and pooling of means and efforts which had become necessary for economic progress'. ${ }^{174}$

Much the same debate that had played out in respect of foreign investment at UNCTAD also played into the framing of this Resolution. As described above, states such as Mexico, Peru, and Chile, saw the multinational corporation as an entity in need of restraint. At the same time, they either implicitly accepted or did not seek to challenge the value of foreign investment as a catalyst for development. Other states, such as Tunisia, saw an inherent contradiction in the fact that 'the developing countries appealed for external capital to strengthen their economies, while on the other

\footnotetext{
166 Ibid [43].

167 Ibid [53].

${ }^{168}$ Appearing to refer to the activities of ITT in Chile, but also noting that other companies far exceeded the economic clout of ITT - such as General Motors, whose sales in 1971 were higher than the GNP of 110 of the then-136 UN member-states: $1831^{\text {st }}$ meeting of the Economic and Social Council, 14 July 1972, UN Doc E/SR.1831 [18]-[21]. The representative of Poland also denounced corporate promotion of 'the interests of neo-colonialism and [interference] openly in national politics': $1832^{\text {nd }}$ meeting of the Economic and Social Council, 20 July 1972, UN Doc E/SR.1832 [33].

$1691831^{\text {st }}$ meeting of the Economic and Social Council, 14 July 1972, UN Doc E/SR.1831 [53].

${ }^{170}$ For example, Denmark, Spain, France, the Netherlands, and especially Poland. The external relations point was emphasised by New Zealand, but by few others: $586^{\text {th }}$ meeting of the Economic Committee, 26 July 1972 , UN Doc E/AC.6/SR.586, 229 (New Zealand).

${ }^{171}$ Ibid 299 (Denmark).

$1721831^{\text {st }}$ meeting of the Economic and Social Council, 14 July 1972, UN Doc E/SR.1831 [41]. Although Argentina was careful to point out that the matters meriting inclusion which concerned developed marketeconomy countries - monopolies and inflation - were very different from those that socialist or developing countries.

${ }^{173}$ Ibid [44] (France). See also the comments by the observer for the Netherlands, who 'assumed that the proposed study was intended to be entirely objective': at [44].

${ }^{174} 1832^{\text {nd }}$ meeting of the Economic and Social Council, 20 July 1972, UN Doc E/SR.1832 [25] (Spain).
} 
hand they complained about the consequences of such investment'. ${ }^{175}$ At the opposite end of the spectrum, the United States rejected any claim that multinational corporations generally had negative impacts, describing such allegations as excessively 'partisan' and 'lacking objectivity'. ${ }^{176}$ Both the US and the UK expressed concerns about the cost of any further study and indicated they were unlikely to support a study which was not 'objective'. ${ }^{177}$

Brazil $^{178}$ suggested the inclusion of an operative paragraph in order for the resolution to more fully 'recognise' the contributions of multinational corporations; vis:

Recognizes that private foreign investment by multinational companies must be subject to national decisions and priorities, facilitate the mobilization of internal resources, generate inflows and avoid outflows of foreign reserves, incorporate adequate technology and enhance savings and national investment. $^{179}$

This was opposed by countries such as Hungary, who felt Brazil's amendments threatened to 'change the whole orientation of the text', ${ }^{180}$ but it was also rejected from the opposite pole by those who felt it did not go far enough. Japan for instance, proposed the insertion of a new paragraph to ensure that 'the study brought out the positive as well as the negative aspects, [since it considered that] the contribution of private investment to the economic development of the third world must not be ignored'. ${ }^{181}$ Although some countries welcomed such statements as 'depoliticising' the terms of reference, ${ }^{182}$ the amendment was forcefully opposed by Chile as threatening to 'upset the delicate balance' that had thus far been achieved. ${ }^{183}$ Poland felt that the Japanese addition 'prejudged the conclusions of the study', and proposed a counter-resolution attesting to transnational corporations' 'excessive exploitation of natural and human resources, and interference in the internal affairs of the developing countries'. ${ }^{184}$ Eventually though, no suitable

\footnotetext{
$1751831^{\text {st }}$ meeting of the Economic and Social Council, 14 July 1972, UN Doc E/SR.1831 [29].

${ }^{176}$ Such as the statements by Poland: $1832^{\text {nd }}$ meeting of the Economic and Social Council, 20 July 1972, UN Doc E/SR.1832 [76] (US).

${ }^{177}$ Ibid [79] (US); $1831^{\text {st }}$ meeting of the Economic and Social Council, 14 July 1972, UN Doc E/SR.1831 [41]-[42] (UK).

${ }^{178}$ By this time a US-supported military dictatorship, which took power through a coup in 1964 against Goulart, a democratically elected left wing President. See, eg, T.E. Skidmore, The Politics of Military Rule in Brazil, 196485 .

$1791832^{\text {nd }}$ meeting of the Economic and Social Council, 20 July 1972, UN Doc E/SR.1832 [18].

$1801832^{\text {nd }}$ meeting of the Economic and Social Council, 20 July 1972, UN Doc E/SR.1832 [50].

$1811834^{\text {th }}$ meeting of the Economic and Social Council, 27 July 1972, UN Doc E/SR.1834, [6].

$182586^{\text {th }}$ meeting of the Economic Committee, 26 July 1972, UN Doc E/AC.6/SR.586, 229 (Indonesia). See also $585^{\text {th }}$ meeting of the Economic Committee, 26 July 1972, UN Doc E/AC.6/SR.585, 223 (Denmark).

${ }^{183} 585^{\text {th }}$ meeting of the Economic Committee, 26 July 1972, UN Doc E/AC.6/SR.585, 219.

184 Ibid 223.
} 
compromise could be agreed on and the rival Japanese and Brazilian amendments were both withdrawn. ${ }^{185}$

The United Kingdom also proposed a number of amendments, the most controversial of which would have removed all references to 'international relations' in the draft resolution. ${ }^{186}$ This was firmly opposed by Chile, as the examination of the impact of multinational corporations on international relations was 'an essential aspect of the draft resolution'. ${ }^{187}$ Eventually, this amendment was withdrawn after the Chilean representative explained changes that had already been made in consultation with the Argentine delegation. ${ }^{188}$ These changes ensured that the work of the study would 'help Governments to take decisions either to promote or to restrict the activities of those corporations, according to the circumstances' without infringing on national sovereignty. ${ }^{189}$

The final question to be resolved was who the 'eminent persons' were to be. There was no question that they would be appointed from a 'broad geographical basis', including representatives of the developed and developing world as well as from the various continents. ${ }^{190}$ Their requisite expertise, however, attracted some debate. Greece objected to the wording of persons intimately acquainted with 'economic and social and international policies' as it was too vague, and thought that referring to 'international trade policy' would be better. ${ }^{191}$ Brazil, on the other hand, considered that confining the study group to experts in international trade policy would limit the scope of study. ${ }^{192}$ Eventually, the negotiations settled on the slightly convoluted phrasing of 'acquainted with international economic, trade and social problems and related international relations'. ${ }^{193}$ Although the USSR had previously objected to the representation of companies in the study group, as they could hardly be expected to support interference in corporate activities, the final wording resolved to appoint experts from both 'the public and private sectors' ${ }^{194}$ Following this, the resolution was approved

\footnotetext{
185 Ibid 225.

${ }^{186}$ For the proposed amendment, see UN Doc E/L.1510. Although the US also wanted to delimit the scope of the resolution by effectively confining it to the context of the study already being undertaken on restrictive business practices, no formal amendment was submitted: see $585^{\text {th }}$ meeting of the Economic Committee, 26 July 1972, UN Doc E/AC.6/SR.585, 226 (United States).

${ }^{187} 585^{\text {th }}$ meeting of the Economic Committee, 26 July 1972, UN Doc E/AC.6/SR.585, 219.

188 Ibid 227 (Inited Kingdom).

${ }^{189}$ Ibid 226 (Chile).

${ }^{190}$ ESC Res 1721 (LIII), 28 July 1972.

${ }^{191} 585^{\text {th }}$ meeting of the Economic Committee, 26 July 1972, UN Doc E/AC.6/SR.585, 221.

192 Ibid 223.

193 Ibid 227.

$1941831^{\text {st }}$ meeting of the Economic and Social Council, 14 July 1972, UN Doc E/SR.1831, [22] (USSR); ESC Res 1721 (LIII), 28 July 1971, [1]. The Group of Eminent Persons was named by the Secretary General. The group comprised twenty people drawn from private companies, government, universities, central banks and.... They are listed by name at page 16 of the final report, 'The Impact of Multinational Corporations on Development and on International Relations'. They were to be assisted by two consultants, Raúl Prebisch and Nat Weinberg:
} 
unanimously by the Economic Committee and adopted by the Economic and Social Council in its $53^{\text {rd }}$ session. ${ }^{195}$

In its final form, Resolution 1721 contained elements of both the technical, developmentalist approach to company-state-international law relations, as well as Allende's approach, which recognised companies as independent, political, international actors. It requested the SecretaryGeneral to appoint a 'group of eminent persons ... to study the role of multinational corporations and their impact on the process of development, especially that of the developing countries, and also their implications for international relations' ${ }^{196}$ It was to report to the Economic and Social Council by the fifty-seventh session at the latest. ${ }^{197}$ Deferring the problem of corporate accountability as a matter of law, the resolution notes the lacuna both as a matter of 'policy....and effective machinery for dealing with the issues raised by the activities of these corporations' ${ }^{\prime 198}$ It proposed that the group would 'formulate conclusions which may possibly be used by Governments in making their sovereign decisions regarding national policy in this respect, and to submit recommendations for appropriate international action,' leaving indeterminate any eventual mechanism through which international law might relate to the questions at hand. ${ }^{199}$ At the same time, the views that had remained unchallenged about the intrinsic value of 'development', fuelled by private foreign capital, were inscribed into the group's terms of reference.

\section{The Group Meets}

The Group of Eminent Persons eventually met between September of 1973 and March of 1974, ${ }^{200}$ even as its composition and progress remained the subject of discussion at further meetings of the Economic Committee of ECOSOC. Lingering concerns revolved around the representation of the interests of developing countries, the organisations from which the members themselves were drawn, and the number of members who were also directors of private companies.

Although the Chilean delegate to the Economic Committee refrained from commenting on the technical competence of the members of the Group, he felt it 'lacked the balance sought in

Department of Economic and Social Affairs, The Impact of Multinational Corporations on Development and on International Relations (1972), UN Doc E/5500/Rev.1 ('Group of Eminent Persons Report')

$1951836^{\text {th }}$ meeting of the Economic and Social Council, 28 July 1972, UN Doc E/SR.1836, [43]-[46].

${ }^{196}$ ESC Res 1721 (LIII), 28 July 1972 [1]. The group was to take into account the work being done on Restrictive Business Practices by the ad hoc group of experts appointed at UNCTAD, as well as research undertaken by the International Labour Office on multinational undertakings and social policy: at [2].

197 Ibid [4].

198 Ibid.

${ }^{199} \operatorname{Res} 1721$ [1].

${ }^{200}$ Group of Eminent Persons Report 19. 
resolution $1721^{\prime}{ }^{201}$ The failure to include trade union leaders or academics from various fields, ${ }^{202}$ combined with over-representation from private companies, did little to fulfil the resolution's requirement that the members of the Group be intimately acquainted with international economic, trade and social problems and related international relations'. ${ }^{203}$ Not only that, but as the resolution had specifically been enacted with a view to preventing 'harmful and criminal activities' of private companies, the inclusion of such a large number of company directors was somewhat counterintuitive. ${ }^{204}$ The USSR, for its part, declared the group's composition to be 'one-sided', in violation of the requirement that the group be appointed on a 'broad geographical basis', since 10 of its members hailed from Western countries while only eight were from developing countries. ${ }^{205}$ Noting that the group's constitution was a 'reflection of the geographical distribution and power of the big multinational companies', Poland expressed concerns about the impartiality of its work. ${ }^{206}$

Opposition to these criticisms was largely absent from the debate before the Economic Committee.

Even Denmark and Sweden, although generally supportive of the progress of the study group thus far in formulating a plan of work, studiously refrained from commenting in any way on the composition of the group. ${ }^{207}$ And despite the concerns expressed elsewhere, no firm push was made to alter the composition of the group at what was perhaps felt to be a late stage. ${ }^{208}$ Responding to the complaints, the Under-Secretary-General for Economic Affairs explained that the fact that the issue with which the group was tasked was a 'transnational phenomenon' required the

${ }^{201} 630^{\text {th }}$ meeting of the Economic Committee, 15 May 1973, UN Doc E/AC.6/SR.630, 166.

202 Specifically referring to the fields of political science, international trade, economics and international affairs: Ibid 167

203 Ibid 166-7 (Chile); ESC Res 1721 (LIII), 28 July 1972.

${ }^{204} 630^{\text {th }}$ meeting of the Economic Committee, 15 May 1973, UN Doc E/AC.6/SR.630, 167. In that respect, the Chilean experience had continued to provide evidence that developing countries were 'extremely vulnerable to the activities of imperialist multinational corporations' - since the passing of the resolution, the US Senate Sub-Committee examining the ITT's activities in Chile had uncovered irrefutable evidence of what Allende had described, while at the same time the Kennecott Company had taken steps to embargo the purchase of Chilean copper, the 'life's blood of the Chilean people', in Europe: at 168-170.

${ }^{205}$ And two representatives were from non-UN member states (FRG and Switzerland), while only two were from socialist countries: $630^{\text {th }}$ meeting of the Economic Committee, 15 May 1973, UN Doc E/AC.6/SR.630, 173. Hungary concurred that the developing and socialist countries were under-represented: $632^{\text {nd }}$ meeting of the Economic Committee, 16 May 1973, UN Doc E/AC.6/SR.632, 210. Pakistan agreed that the underrepresentation of the developing countries was a problem, and regretted that they had not been contacted during the Secretary-General's 'extensive informal consultations' undertaken as part of the selection process: $630^{\text {th }}$ meeting of the Economic Committee, 15 May 1973, UN Doc E/AC.6/SR.630, 175-6.

${ }^{206} 632^{\text {nd }}$ meeting of the Economic Committee, 16 May 1973, UN Doc E/AC.6/SR.632, 208-9.

${ }^{207} 631^{\text {st }}$ meeting of the Economic Committee, 15 May 1973, UN Doc E/AC.6/SR.631, 195 (Denmark); $632^{\text {nd }}$ meeting of the Economic Committee, 16 May 1973, UN Doc E/AC.6/SR.632 206-7 (Sweden).

${ }^{208}$ Chile stated that it had not meant to push for alteration of the group's membership, and that the group should be set up as soon as possible: $631^{\text {st }}$ meeting of the Economic Committee, 15 may 1973, UN Doc E/AC.6/SR.631, 196. Subsequently, Pakistan withdrew its proposal to increase the group's membership to 24 rather than 18 representatives, although it continued to insist that the group's work should focus on the situation of the developing countries: SR $632^{\text {nd }}$ meeting of the Economic Committee, 16 May 1973, UN Doc E/AC.6/SR.632, 210-11. 
representation of 'transnational viewpoints' and therefore, a departure from the ordinary principle of equitable geographical distribution. ${ }^{209}$ While problems such as those Chile had described would arise 'because of the inevitable tension which existed between the various forms of power...it was necessary to look to the future...to ensure that multinational corporations played a positive role in the developing countries'. ${ }^{210}$ In closing the debate, the United States delegate sought to minimise the relevance of the equal geographical distribution question: '[i]rrespective of the regions or circles from which they came, the members of the Group had all the qualities needed to evaluate objectively the impact of multinational corporations'. ${ }^{211}$ And for those concerned about the focus of the Group's work, he reassured them that all members, regardless of their origins, had a shared 'bias toward development'. ${ }^{212}$

\section{The Report}

With both its terms of reference and personnel being debated to the last, the Group of Eminent persons issued a report on 22 May, 1974 entitled the 'Impact of Multinational Corporations'. ${ }^{213}$ Despite all that had gone before, the Group recommended that a Commission on multinational corporations be established to assist the work of the Economic and Social Council. ${ }^{214}$ The complexity and breadth of the issue of multinational corporations required a 'continuing elucidation and analysis of the problems involved, based on more information, professional studies and consultations with the various parties concerned'. ${ }^{215}$ The Commission was to be composed of members serving in an individual capacity, hailing from both developed and developing states and from a variety of professions. ${ }^{216}$ It would meet at least once a year and act as a 'focal point' through

\footnotetext{
${ }^{209} 632^{\text {nd }}$ meeting of the Economic Committee, 16 May 1973, UN Doc E/AC.6/SR.632, 213 (de Seynes).

210 Ibid 214.

211 Ibid 218.

212 Ibid 218. Although these states and others, including Algeria, Hungary and Mongolia, would continue to express their concerns later in that year, no change was made to the candidates thus far selected apart from the addition of Mario Trindade (Brazil), Vice President of the National Bank of Commerce. See 'The Impact of Multinational Corporations on the Development Process and on International Relations: Progress Report of the Secretary-General', 11 May 1973, UN Doc E/5334. On the concerns of some states about the composition of the group, see $651^{\text {st }}$ and $652^{\text {nd }}$ meetings of the Economic Committee, 27-30 July 1973, UN Doc E/AC.6/SR.6512

${ }^{213}$ Group of Eminent Persons Report.

${ }^{214}$ Ibid 52. This recommendation was fully endorsed by the UNCTAD Secretary-General: at 6.

${ }^{215}$ Ibid 52.

${ }^{216}$ Ibid 57-58. The rationale for this, the Secretary-General's report stated, was that a non-governmental body would 'facilitate the consultation process and encourage greater involvement', including by private parties. In fact, the Secretary-General went so far as to suggest that the achievements of the Group itself would likely not have been possible had it been constituted by states: at 7 .
} 
which the Economic and Social Council could debate, consider and respond to issues posed by multinational corporations. ${ }^{217}$

The proposed terms of reference for the Commission were, for the most part, open-ended. It would receive reports and provide a venue for the exchange of views among states, organisations and multinational corporations themselves. ${ }^{218}$ The report also recommended that the Commission undertake a programme of technical capacity-building of host countries to strengthen their position in negotiations to multinational corporations. ${ }^{219}$ Partly to facilitate this, the Group proposed that an information and research centre on MNCs be established to assist the Commission by performing administrative tasks, conducting research and disseminating information, and coordinating 'technical cooperation' programmes for the developed world. ${ }^{220}$

The Commission would now also serve to facilitate a process which had been ongoing in other fora - namely, the 'adoption of specific arrangements or agreements in selected areas pertaining to the activities of multinational corporations', such as restrictive business practices or transfer of technology. ${ }^{221}$ In contrast to these piecemeal efforts, however, it should act holistically to 'evolve a set of recommendations which, taken together, would represent a code of conduct for Governments and multinational corporations'. ${ }^{222}$ Although there was significant difference of opinion about what such a code should entail, the GEP clarified that in its view, the proposed code of conduct should not be compulsory in character but would 'act as an instrument of moral persuasion' for multinational corporations. $^{223}$

The more controversial aspect of the Commission's task was to 'explore the possibility of a general agreement on multinational corporations, enforceable by appropriate machinery, to which participating countries would adhere by means of an international treaty'. ${ }^{224}$ Although this was included in the set of recommendations transmitted to ECOSOC, the GEP itself considered that it would be 'premature to propose serious negotiations on such an agreement' as significant preparation was required. ${ }^{225}$ In the meantime, the Group reasoned, action on more 'specific issues' could take place, such as taxation or labour arrangements which could be concluded without such

\footnotetext{
${ }^{217}$ Ibid 57-58.

218 Ibid 57, recommendations (b) and (c).

219 lbid 36-8.

${ }^{220}$ Ibid 53-4.

${ }^{221}$ Ibid 57 recommendation (d).

222 Ibid 57 recommendation (e).

${ }^{223}$ Ibid 55.

${ }^{224}$ Ibid 57 recommendation (f).

225 Ibid 54.
} 
delay. ${ }^{226}$ In this way the Group's conviction that the benefits which can be derived from multinational corporations are fully realised' could be implemented. ${ }^{227}$

As one might have expected given the temperature of the debates leading up to the report, the response was also lively. One immediate response by some within the Group itself, related to something understood to have been lost in translation between a background document and the report itself. This document, prepared by the Department of Economic and Social Affairs of the UN Secretariat to assist the work of the GEP, ${ }^{228}$ had aimed to 'clarify various concepts pertaining to multinational corporation, provide[] basic data on their size, geographical distribution, industrial structure and ownership patterns, and assess their dimensions in the world economy'. ${ }^{229}$ However, in its final form, it went further, assessing the multinational corporations' 'impact on international relations, and on home and host countries, including tensions that may develop between them and these countries'. ${ }^{230}$

Unlike the report of the Group of Eminent Persons, the background document openly stated that the 'political and social dimensions of the problem of multinational corporations [were] only too apparent'. To illustrate these, it meticulously laid out a series of facts including those concerning the pattern of corporate distribution, and concluded that it closely mirrored the pattern of former colonial ties. ${ }^{231}$ The international economic system that had been developed earlier in that century further complicated this picture, as the porousness of national economic boundaries no longer corresponded to political-legal conceptions of national sovereignty. ${ }^{232}$ The critical question for the writers of that background report, therefore, was not what benefit could be derived from the company as a carrier of investment, but 'whether a set of institutions and devices can be worked out which will guide the multinational corporations' exercise of power and introduce some form of accountability to the international community into their activities' ${ }^{233}$

From comments made by members of the Group, it is clear the political-economic orientation of that document sat uneasily with the more technical and developmentalist orientation of the GEP report.

\footnotetext{
${ }^{226}$ Ibid 54.

227 Ibid 26.

${ }^{228}$ Ibid 3. It is unclear at whose request this report came about.

${ }^{229}$ Department of Economic and Social Affairs, Multinational Corporations in World Development (1973), UN Doc ST/ECA/190, vi

${ }^{230}$ Ibid vi

231 Ibid 1, 9.

232 Ibid 3: 'However sacred and inviolable national sovereignty may be from the political point of view, few national boundaries correspond to economic demarcation lines and few states are self-contained economic entities'.

${ }^{233}$ Ibid 2. The report was strongly skeptical of the ability of non-binding measures, such as the code of conduct proposed by the Group, to achieve this end: Ibid 78-9
} 
One delegate, Juan Somavia, ${ }^{234}$ suggested that the analysis contained in the background document should continue to live side by side with the Group's report as a necessary complement to its perceived limitations. ${ }^{235}$ He criticised the 'tendency of the report to concentrate on the microrelationship between a multinational corporation and a given country' and corresponding neglect of the multinational corporation as situated within the history of international political and economic relations. ${ }^{236}$ In doing so, it was blind to the multinational corporation as 'the expression of a ... system whose values, basic orientations and general structure have stimulated their unprecedented expansion'. ${ }^{237}$ Another delegate, Ahmed Ghozali, ${ }^{238}$ pointed to the absence in the report of any mention of the events which had happened since the initiative had begun. ${ }^{239}$ First among these was the 'Chilean tragedy' - the coup in Chile and the death of Salvador Allende, perhaps what Allende had feared when he launched the initiative. ${ }^{240}$ For both Ghozali and Somavia, the divorcing of the problem of multinational corporations from both politics and history augured badly. Both were essential to understanding the conditions that had given rise to this phenomenon, to producing a new type of relationship between corporations and states adequate to the task of securing the autonomy of the Third World, and to ensuring a fairer international distribution of wealth in the future.

When the report eventually came before the Economic and Social Council at its $57^{\text {th }}$ session, the initial response to the recommendations of both the Group of Eminent Persons and the SecretaryGeneral was strikingly pragmatic. The Netherlands, for instance, called for the Council to 'take up the recommendations ... and translate them into practical measures' without delay in order to create the desired set of new relations between the developed and developing world. ${ }^{241}$ There was a difference in emphasis over the Commission's most urgent programme of work: many states, as well as the representative from the International Chamber of Commerce, ${ }^{242}$ emphasised the importance

\footnotetext{
${ }^{234}$ Later to be Director General of the ILO.

${ }^{235}$ Group of Eminent Persons Report, 162 (Comments by Juan Somavia). Juan Somavia was the Chilean Former Permanent Representative to the Andean Group, Former President of the Commission of the Cartagena Agreement, and Former Chairman of the Board of the Andean Development Corporation. See also the comments of Ahmed Ghozali on this point, at 103.

236 Ibid 162.

237 Ibid.

${ }^{238}$ Then Minister of Energy and Investment of Algeria.

${ }^{239}$ Ibid 103. Ahmed Ghozali was the President Director-General of SONATRACH, an Algerian state-owned company.

${ }^{240}$ Also developments in relation to energy and raw materials, which would have shed 'essential light both on the role of multinational corporations and the machinery of their operations and on the problems and aspirations of the developing countries': Ibid.

${ }^{241} 1901^{\text {st }}$ meeting of the Economic and Social Council, 4 July 1974, UN Doc E/SR.1901, [71]. See also $1902^{\text {nd }}$ meeting of the Economic and Social Council, 4 July 1974, UN Doc E/SR.1902, [8] (Canada); $1903^{\text {rd }}$ meeting of the Economic and Social Council, 5 July 1974, UN Doc E/SR.1903, [43]-[44] (Mexico);

${ }^{242} 1906^{\text {th }}$ meeting of the Economic and Social Council, 8 July 1974, UN Doc E/SR.1906, [65]
} 
of the (nonbinding) code of conduct. Others, such as India, considered that the body 'should take up as a matter of priority the development of a [binding] regulatory framework'. ${ }^{243}$ And, although some states were in favour of the commission being constituted by experts, as the GEP had suggested, ${ }^{244}$ others felt strongly that it should be constituted by states, with experts playing a supplementary role. ${ }^{245}$ In short order, the Chairman of the Group presented the report to the Economic Committee. Given the limited time available to debate the report, both the UK and Canada proposed that the Committee confine itself to the 'passages which concerned international machinery and action'. ${ }^{246}$ The debate which followed showed that states had by this time become committed to the establishment of the proposed Commission in one or another form - as Algeria argued, the work of the Group had to be continued and it was 'superfluous ... to ask whether new machinery was desirable or necessary'. ${ }^{247}$ Only China voiced a concern that the report had failed to reflect the 'plundering and exploitation of the developing countries perpetrated by the multinational corporations' and that the recommendations of the report should be viewed with caution. ${ }^{248}$

The Economic Committee reached agreement on 1 August on a resolution deciding in principle to establish permanent machinery 'to assist the Council in dealing with the issue of transnational corporations'. ${ }^{249}$ The resolution convened a Special Intersessional Committee of the Council to more closely examine the report and the views of States on its recommendations. ${ }^{250}$ By 5 December 1974 the Intersessional Committee had unanimously recommended Resolution 1913 to the Council. ${ }^{251}$

That resolution would establish a 48-member inter-governmental body, with states to be elected 'on a broad and fair geographical basis', to be called the Commission on Transnational Corporations. ${ }^{252}$ It was to be composed of experts appointed by those states and supported by an information research

\footnotetext{
$2431903^{\text {rd }}$ meeting of the Economic and Social Council, 5 July 1974, E/SR.1903 [35].

$2441905^{\text {th }}$ meeting of the Economic and Social Council, 8 July 1974, E/SR.1905, [8] (Pakistan); $1906^{\text {th }}$ meeting of the Economic and Social Council, 8 July 1974, UN Doc E/SR.1906, [11] (United Kingdom).

$2451901^{\text {st }}$ meeting of the Economic and Social Council, 4 July 1974, UN Doc E/SR.1901 (Brazil); also $1905^{\text {th }}$ meeting of the Economic and Social Council, 8 July 1974, E/SR.1905, [58] (Yugoslavia). Except for the Chilean representative, who did not feel it was necessary to establish the commission in order to deliver a 'mandatory code of conduct': $1911^{\text {th }}$ meeting of the Economic and Social Council, 11 July 1974, UN Doc E/SR.1911, [12]. $246705^{\text {th }}$ meeting of the Economic Committee, 18 July 1974, E/AC.5/SR.705, 197 (Canada). See also at 198 (United Kingdom).

$247708^{\text {th }}$ meeting of the Economic Committee, 19 July 1974, UN Doc E/AC.6/SR.708, 233.

$248707^{\text {th }}$ meeting of the Economic Committee, 19 July 1974, UN Doc E/AC.6/SR.707, 218.

${ }^{249}$ Which was adopted without a vote the next day by the Economic and Social Council as resolution 1908: ESC Res 1908 (LVII), 2 August 1974, [6].

250 lbid [7].

${ }^{251}$ No summary records exist of the Committee's deliberations, and the final consensus was reached through informal consultations: $1931^{\text {st }}$ meeting of the Economic and Social Council, 5 December 1974, UN Doc E/SR.1931. See also 'Report of the Special Intersessional Committee', 8 January 1975, UN Doc E/5599.

${ }^{252}$ ESC Res 1913 (LVII), 5 December 1974, [1].
} 
centre. ${ }^{253}$ Although the programme of work for the Commission remained relatively unchanged from the report of the GEP, there was one notable difference: the task of creating an international treaty adequate to the problems that Allende had outlined had been dramatically deemphasised. Instead, the Commission was now to consider 'possible arrangements or agreements on specific aspects relating to transnational corporations with a view to studying the feasibility of formulating a general agreement and...to consolidating them into a general agreement at a future date' ${ }^{254}$ The possibility of an enforceable agreement which could reimagine the place of the transnational corporation in the international order seemed remote indeed. ${ }^{255}$

\section{V. 'Our Common Success': The establishment of the UNCTC and the Kissinger response to the New International Economic Order}

By the time of the first session, in March of 1975, the question of a treaty had fallen off the Commission's programme of work altogether. Instead, efforts refocused on the proposed (and potentially non-binding) 'code of conduct', to be taken up by the Commission as a matter of priority. ${ }^{256}$ However, the Commission's preparation for negotiations on a code of conduct could only proceed through putting to one side two unresolvable questions. The first was the question of the enforceability or mandatory nature of the code; the second was whether, under it, governments would also be subject to obligations. ${ }^{257}$

At around the same time, and as part of the ongoing efforts to establish the principles of a New International Economic Order, the General Assembly had resolved to hold a Special Session on development and international economic cooperation, to be held from 1 September $1975 .{ }^{258}$ The purpose of the session was to consider 'new concepts and options with a view to promoting effectively the solution of world economic problems, especially those of developing countries' ${ }^{259}$ At the very forefront of the session was the United States, the second State to speak. ${ }^{260}$ Then US Secretary of State, Henry Kissinger, intending to be present, instead wrote a speech which was read

\footnotetext{
253 Ibid [4].

254 Ibid [4]. Compare to the wording of the recommendations made by the Group of Eminent Persons, supra note 194.

${ }^{255}$ For the way in which this was taken up at the first session of the Commission, see Commission on Transnational Corporations, 'Report on the First Session (17-28 March 1975)', UN Doc E/5655

256 Ibid 2.

257 Ibid 9.

${ }^{258}$ This was in the wake of the Declaration establishing a New International Economic Order at the UN General Assembly in 1974: 'Declaration on the Establishment of a New International Economic Order', GA Res 3201 (SVI), 1 May 1974, UN Doc A/RES/S-6/3201.

${ }^{259}$ PV 2327 [3] (Brazil), citing GA Res 3172 (XXVIII).

${ }^{260}$ After Brazil: PV 2327.
} 
in his absence - 'a programme of practical steps' to address the concerns of the developing world. ${ }^{261}$ In contrast to the Third World's insistence on the continued presence of history, for Kissinger the moment was ruptural, representing a radical break with the past: the 'global order of colonial power that lasted through centuries has now disappeared'. ${ }^{262}$ Even 'the cold war division of the world into two rigid blocs ha[d] now also broken down', and there remained, he said, only states united in the common endeavour of development. ${ }^{263}$ And yet Third World solidarity was positioned in opposition to the inauguration of what could be a new era of 'human progress.' The threat lay in the formation of the Non-Aligned Movement, a 'new bloc' which was counter-productive to this endeavour, engaging 'in a kind of solidarity that often clearly sacrifices practical interests'. ${ }^{264}$ What was required to address the economic problems faced by all states was not division, said Kissinger, but 'consensus, first and foremost, on the principle that our common development goals can be achieved only by co-operation, not by the politics of confrontation' ${ }^{265}$

The 'transnational enterprise' was amongst the most contentious of these lines of 'political division'. The ongoing 'controversy over their role and conduct' which had continued in various forms and fora since Allende's speech was 'itself an obstacle to economic development'. ${ }^{266}$ In his view, 'if the world community [was] committed to economic development, it [could] not afford to treat transnational enterprises as objects of economic warfare. ${ }^{267}$ Nevertheless, Kissinger conceded that 'the time [had] come for the international community to articulate standards of conduct' for corporations, and acknowledged that the UNCTC, 'had begun such an effort'. But for Kissinger, 'transnational enterprises ha[d] been powerful instruments of modernization', and 'may well be one of the most effective engines of development'. ${ }^{268}$ And given that only 'transnational enterprises' could facilitate the solution to the problem of under-development, standards should be formulated which applied both to the behaviour of corporations and to the governments that hosted them. ${ }^{269}$

The principles that Kissinger laid out underpinning these standards were extensive, but two elements were key to the question of the transnational corporation. First was an insistence that corporate conduct should be governed by local, not international law. Transnational corporations were of course 'obliged to obey local law' and should 'refrain from unlawful interference in the

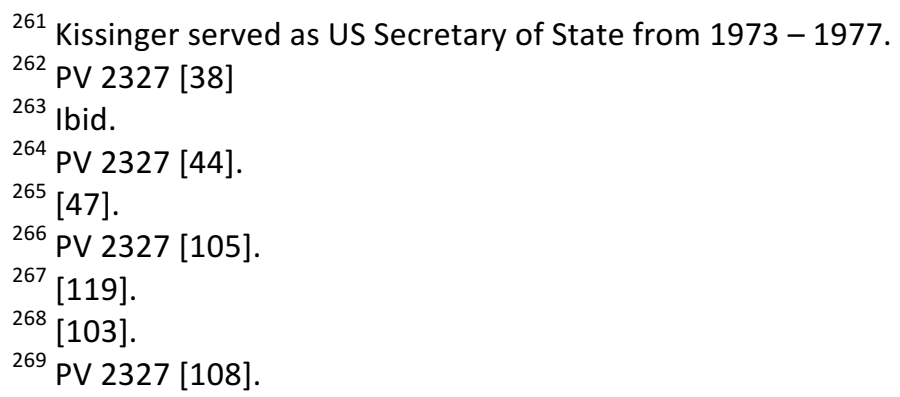


domestic affairs of the host country', 'respect local customs and employ qualified local personnel' ${ }^{270}$ But second, in return, those corporations must receive a stable, apolitical environment in which to operate, characterised by equitable and non-discriminatory treatment. And unlike corporate conduct governed by local law, 'host states' must accord transnational enterprises protection 'in accordance with international law'. ${ }^{271}$ In Kissinger's account, these protections would be supported by a suite of international endeavours, including the harmonisation of tax treatment, the promotion of arbitral procedures for the settlement of investment disputes, the reduction of restrictive business practices, and the multilateralization of the insurance of foreign investment. ${ }^{272}$ These would be underpinned by the 'development of agricultural technologies' for food production, 'assistance to improve productivity and competitiveness' in relation to non-agricultural food production, and the assurance of future access to 'borrowing in the [international] capital market', which was already relied upon heavily in the Latin American countries. ${ }^{273}$ In essence, what Kissinger was mapping was a different kind of 'new international economic order,' one which drew for its authority on 'development', and the needs of the poorest 'one billion people', ${ }^{274}$ but which precisely contradicted in its every element the other 'New International Economic Order' being proposed by the Global South at the same moment. At the centre of this map, stabilised by the failure to operationalise opposition to the investment-as-development shibboleth, was the assertion of the impossibility of international legal control of the company. And as we know now, Kissinger's map was prefigurative of what was to come.

\section{Conclusion}

Much is at stake in how we narrate past struggles. Many conflicts between different groups of people may be recounted either as political contestations over the 'proper' meaning of things within a pre-constituted frame, or as more radical struggles over the frame of reference through which meaning is to be determined. The stakes are particularly high when jurists are involved, for when we write about 'law' in the context of struggle, we are also participating in the construction, diffusion and stabilisation of the authority of the 'law' in the name of which we write. ${ }^{275}$ The problem is especially acute for international lawyers, who sit perennially at the crossroads of difference, or at the point of encounter between plural traditions, and multiple laws. ${ }^{276}$ When international lawyers

\footnotetext{
${ }^{270}$ PV 2327 [110].

${ }^{271}$ PV 2327 [111]. Emphasis added

${ }^{272}$ PV [112]-[118]

273 [84]

$274[165]$

${ }^{275}$ Not for nothing does 'doctrine'/la doctrine (as in 'teachings') have an ambiguous etymology and ongoing life, signaling 'the rules' in English, but 'scholarly writings' in French.

${ }^{276}$ Pahuja, Laws of Encounter supra note 5; Letters from Bandung, supra note 5.
} 
write about struggles over and around 'International Law' as though the battle were self-evidently a question of politics, empirical fact, content, legitimacy, or a bid for 'inclusion', rather than (also) a meeting of, and struggle between different legal traditions or different laws, we join in a project of both authoring 'International Law', and authorising that particular international law. When such struggles are in the past, our retrospective acts of authorisation take on a teleological cast, ${ }^{277}$ and participate in practices of international legal historiography through which encounters - whether diplomatic, developmental or genocidal - between radically different traditions of law, are ultimately smoothed over into a story of the progressive expansion, if not the 'universalisation' of 'one' international law.

In the battles over the relationship between states, corporations and international law, Allende's radical critique of the corporate form, the company's historical exercise of political authority, its capacity to travel and the power that capacity engendered, were taken up in ways which planted the seeds for the adverse effects of corporate activity to be exceptionalised, for foreign investment to be normalised, and for private capital flows to be related axiomatically to 'development.' These discursive shifts both effected and were reinforced by the stabilisation of particular legal forms, including the institution of private property, and the 'private' corporation whose legal personality could travel across national borders. In turn, these re-framings began to legitimise what was later to become an article of faith in many quarters - that the core, 'normal', activity of corporations was unquestionably 'good', and that a sphere of corporate freedom of action was therefore needed. What our story reveals is that as the experiential, historical knowledge being insisted upon by the Second and Third Worlds, gave way to the 'expert' knowledge generated in the First world, the effects of corporate activity and private foreign investment came gradually to be redescribed as apolitical questions, and the difficulties came slowly to be understood as questions of technique rather than challenges of one political agenda - and it vision for international law - to another. Debates about regulation accordingly became increasingly technical, conducted amongst gatherings of experts and business leaders, and cloistered from political scrutiny. ${ }^{278}$ Questions about the ways in which the activities of powerful corporate actors engaged fundamental questions about international relations, as well as how to live and promote a good life grew increasingly distant, until they seemed to disappear altogether from the horizon of institutional concern. And yet slowing

\footnotetext{
${ }^{277}$ Richard Drayton, 'Where does the World Historian Write From? Objectivity, Moral Conscience and the Past and Present of Imperialism' 46(3) Journal of Contemporary History 671-685 at 671. Drayton was writing of contemporary history as an idea, but the same can be said of contemporary histories of international law. ${ }^{278}$ David Kennedy tells a contemporary story of this transformation of politics and government to expertise and governance in World of Struggle. The generalisation of this transformation is perhaps an example of the way in which 'we are all developing countries now'. I borrow this phrase from Kerry Rittich.
} 
down our study of this moment reveals that much of what was at stake then remains so today, and that as long as they are imaginable, other worlds are still possible.

\section{Epilogue}

'The corporate phase of the empire remains, though not in its old form; its pre-colonial form has mutated into postcolonial corporate rule, almost as if the colonial period was an interregnum in the continuity of corporate rule.'

Ngūgī wa Thiong'o 279

Periodisation is always an argument, never a fact. The years between 1955 and 1974 repay a slow re-reading but perhaps not for the reasons we might imagine. In the incipient telos implied by the two dates, 1974 stands as the 'culmination' of the initiative launched at Bandung in 1955. And the twin declarations of the New International Economic Order, ${ }^{280}$ and the Charter of Economic Rights and Duties of States ${ }^{281}$ seem like the 'high water mark' of the Bandung spirit. In that story, the high tide of solidarity suddenly retreated before the tsunami of the debt crisis which broke close to a decade later.

But by contemporaneous accounts, the decades moved slowly. And the demand for a wholesale, 'new international economic order' seems to have become necessary in part because the initiatives for self-help and international reorganisation taken by the Third World were strongly resisted by the First World. The 'spirit of Bandung' is perhaps what kept those initiatives alive, displacing First world resistance to Third World change through struggles which moved into different fora and morphed into different forms. When we move slowly through the archive of the two decades at hand, we see that these years may perhaps be better read as a time during which the Third World was attempting to assert its authority on the international level, and specifically a capacity to decide, but in which the water was rising perilously all the time.

For the battle over transnational corporations, the arc between 1955 and 1974 is both particular and generalisable. The creation of the UNCTC would appear to have been a victory of sorts, but it failed to produce the collective state action sought by the Third World to regulate the conduct of multinational corporations. The UNCTC was quietly put to rest in 1993, folded into the UNDP as part of the 'Division on Investment and Enterprise.' Today that particular attempt to establish a conversation at the United Nations about multinational corporations is almost invariably forgotten. When it is remembered at all, it is characterised as an ill-fated attempt to assert a Third World

\footnotetext{
${ }^{279}$ Resisting Metaphysical Empires: Language as a War Zone (2014, New Beacon Books: London), 18.

${ }^{280} 1$ May 1974

${ }^{281} 12$ December 1974
} 
sovereign jurisdiction against an international jurisdiction, with all the hierarchies of value that characterisation implies. The story is now largely retold (for better or worse) as 'sovereignty' versus international 'community'.

But perhaps more accurate than both that story, and a narrative of the 'failure' of the initiative, is a story of the eventual inversion of what was being attempted. Not a simple 'domestic' versus 'international' story, but an attempt to put different matters into the basket of 'domestic' versus 'ínternational', and with differential consequences. As it emerged from formal empire, the Third World sought to assert authority over private property in the national realm, and to internationalise the capacity to regulate corporate conduct as a response to the essential rootlessness of the multinational corporation. But what we have seen during the period from the end of the Cold War to the present is the internationalization of the protection of private property through an emerging regime of 'international investment law', and the relegation to the national sphere of the regulation over corporate conduct, along with the vulnerabilities and collective action problems that brings. Tracing the story beyond the year $1974^{282}$ reveals that the narrative arc is not that of an arrow which is shot up but falls to the ground, but the arc of the boomerang, in which we launch something into the world and 'it comes back and hits us in the face. ${ }^{283}$ This is the narrative arc of tragedy.

\footnotetext{
${ }^{282}$ Pahuja, LIL piece, forthcoming.

283 Interview with Philosopher Simon Critchley, 'Critchley explains Tragedy's philosophy' http://humanities.byu.edu/critchley-explains-tragedys-philosophy/. We owe this reference to Adil Khan.
} 


\section{University Library}

\section{- M M N E R VA A gateway to Melbourne's research publications}

Minerva Access is the Institutional Repository of The University of Melbourne

Author/s:

Pahuja, S;Saunders, A

Title:

Rival Worlds and the Place of the Corporation in International Law

Date:

2019

Citation:

Pahuja, S. \& Saunders, A. (2019). Rival Worlds and the Place of the Corporation in International Law. von Bernstorff, J (Ed.). Dann, P (Ed.). The Battle for International Law: South-North Perspectives on the Decolonization Era, (1), pp.141-174. Oxford University Press.

Persistent Link:

http://hdl.handle.net/11343/251330 